\title{
A global snapshot of marine biodiversity offsetting policy
}

Holly J. Niner ${ }^{a^{*}}$, Ben Milligan ${ }^{b}$, Peter J.S. Jones ${ }^{c}$, Craig A. Styan ${ }^{a}$

\author{
a University College London, Australia. Torrens Building, 220 Victoria Square, Adelaide 5000, Australia \\ b Centre for Law and Environment, University College London, Bentham House, Endsleigh Gardens, \\ London WC1H OEG, United Kingdom \\ ${ }^{c}$ Department of Geography, University College London, Pearson Building, Gower Street, London WC1E \\ 6BT, United Kingdom
}

* Corresponding author: holly.niner.13@ucl.ac.uk

\begin{abstract}
Biodiversity offsetting is used in diverse policy contexts to reduce, halt or reverse losses of biodiversity arising from development or other uses of the natural environment. Despite increasing interest in the concept of biodiversity offsetting, relatively little attention has been devoted to investigating its use in marine environments. This paper presents a systematic review of documents evidencing the application or inclusion of biodiversity offset principles in policy frameworks concerning the marine environment, and in marine development projects. Biodiversity offsetting policies applicable to marine environments were found to exist in six countries (US, Canada, Australia, France, Germany, Colombia) and have been actively considered in at least 27 others. Outside of these, a wide range of other approaches promoting uptake of biodiversity offsetting principles in a marine context were identified. These range from preliminary studies to identify potential compensatory habitat, to nascent biodiversity markets, and project-level application of corporate standards of no net loss. Evidence suggests that where offsetting policy is developed for specific marine application, the preferred approach is to pool financial contributions from developers into funds for strategic action for biodiversity benefit.
\end{abstract}

\section{Keywords}

No net loss; Compensation; Marine offsets; Mitigation hierarchy

\section{Highlights}

- Global review of marine biodiversity offsetting policy and practice.

- Public policy frameworks for marine biodiversity offsets exist in US, Canada, Australia, France, Germany and Colombia.

- Marine biodiversity offsetting principles applied outside of public policy frameworks in at least seven countries.

- Biodiversity offsetting principles are applied in marine contexts in diverse forms.

This is the authors' version of the final accepted Marine Policy manuscript. Elsevier(C) 2017. This manuscript version is made available under the CC-BY-NC-ND 4.0 license. DOI:10.1016/i.marpol.2017.04.005.

\section{cc) coative}




\section{Introduction}

Damage to natural environments and their widespread conversion for other uses are contributing to the accelerating decline of global biodiversity [1,2]. Biodiversity offsetting is one of many proposed approaches for mitigating losses of biodiversity associated with economic and infrastructure development projects [3]. The underpinning principle of biodiversity offsetting is 'no net loss' (NNL) i.e. the counterbalancing of biodiversity losses with biodiversity gains [4]. These gains can be realised through various mechanisms including; restoration or rehabilitation of habitat in another location, averted loss e.g. through the protection of an area and education, and management to alleviate or avert pressures that would lead to biodiversity losses [3]. Other mechanisms such as allocation of funds for research have also been characterised as biodiversity offsets in contexts where lack of knowledge is considered an impediment, however these are considered to be very 'out of kind' and difficult to reconcile with the principle of NNL $[5,6]$.

Conceptually, the implementation of biodiversity offsets can take one of three forms: (1) ad-hoc projects delivered directly by the proponent of development causing biodiversity loss; (2) third party habitat banks (also referred to as species, conservation or mitigation banks) where 'biodiversity credits' equivalent to meeting offsetting requirements can be purchased or otherwise exchanged; and, (3) in-lieu fees where financial compensation for biodiversity impacts is pooled for strategic level conservation projects $[3,7]$. To guide the appropriate application of biodiversity offsets a set of key principles have been widely accepted as necessary for the success of the approach [4] (Table 1). 
Table 1. Key principles for biodiversity offsetting success.

\begin{tabular}{|c|c|}
\hline Principle & Detail \\
\hline Mitigation hierarchy & $\begin{array}{l}\text { Biodiversity offsets should be considered only as a last resort for residual impacts after } \\
\text { avoidance and mitigation has been explored [5]. This exercise should be informed by a feasibility } \\
\text { study of offsets (accounting for principles identified as essential for biodiversity offset success } \\
\text { including equivalence, additionality, continuity and compliance monitoring) and an analysis of } \\
\text { the ecological significance of the identified impact }[5,8] \text {. }\end{array}$ \\
\hline Equivalence & $\begin{array}{l}\text { Demonstration of the balance between biodiversity losses and gains is required }[4,8,9] \text {. This } \\
\text { should take account of the counterfactual baseline to ensure NNL is achieved }[10] \text {. }\end{array}$ \\
\hline Additionality & $\begin{array}{l}\text { Biodiversity offsets should not displace existing commitments or activity; they should deliver } \\
\text { benefits beyond those that would occur in the absence of the offset project }[4,11] \text {. Biodiversity } \\
\text { offsets should be designed in context so as to complement existing conservation priorities and } \\
\text { to prevent displacement of impact to other areas (leakage) [12]. }\end{array}$ \\
\hline Continuity & $\begin{array}{l}\text { Supply of biodiversity through offset projects requires consideration from a temporal and } \\
\text { financial perspective. Temporal strategies should ensure that the point at which NNL of } \\
\text { biodiversity is achieved is matched to the point of impact }[5,13-15] \text { and that outcomes are } \\
\text { delivered for the duration of the impact or in perpetuity }[5,16] \text {. This should be managed through } \\
\text { an associated adaptive monitoring program the finances of which should be fully accounted for } \\
\text { within planning }[8,17] \text {. }\end{array}$ \\
\hline Compliance success & $\begin{array}{l}\text { Non-compliance with biodiversity offset requirements is a significant risk to achieving an aim of } \\
\text { NNL. Whilst the legal responsibility for the success of the offset project lies with the project } \\
\text { proponent or third-party delivering the offset, oversight of implementation (and monitoring) } \\
\text { should be maintained by a third party or regulator to ensure compliance with the offsetting } \\
\text { requirements [3,18-21]. These relative responsibilities should be clearly outlined and the } \\
\text { mechanisms by which this oversight will be undertaken to ensure implementation occurs and is } \\
\text { in line with that agreed. }\end{array}$ \\
\hline
\end{tabular}


Discussion and use of biodiversity offsetting has rapidly increased over the last decade for a number of reasons [8]. Political agendas to promote use of market-based instruments for conservation purposes has been identified as one of the main drivers for uptake of the approach [8]. This political push has outpaced the development of ecological foundations for the approach which are yet to be clearly defined [8]. Given the knowledge gaps in the underpinning ecological science, the outcomes of biodiversity offsetting in terms of environmental protection are unclear [9]. The challenges of this approach include those concerning our fundamental ability to restore ecology [10], inappropriate implementation and design of offsets [11], the need to seek equivalence across ecological components and ineffectual compliance regimes [3,12-14].

Biodiversity offsetting practice in terrestrial areas has been subject to a level of academic scrutiny but less attention has been devoted to the extension of the practice into marine environments [15]. Given that increasing development pressures and impacts are not confined solely to terrestrial environments and with projections for the 'ocean economy' to more than double between 2010 and 2030, it follows that biodiversity offsets are likely being increasingly applied offshore [14,16-18]. Current indications are that the challenges posed by the use of biodiversity offsetting policies in the marine environment are common to those faced in terrestrial applications [14]. The marine environment, however, presents unique difficulties including the scale and degree of connectivity between and within ecological units operating in three dimensions [19], high biological and physical heterogeneity of both habitats and species on widely varying spatial and temporal scales [19], poorly defined property rights and the remote nature of governance relative to population centres [20-22].

Available literature is limited to analysis of the marine application of existing and relatively mature national biodiversity offsetting policies in the US, Canada and Australia [23-26]. Efforts to identify marine practice in Europe have struggled to find evidence of the use of biodiversity offsetting owing to the way in which the mitigation hierarchy has been applied within impact assessment $[15,22,27]$. Beyond this little is known about how and where biodiversity offsetting theory is being applied in a marine context $[14,22]$.

This paper seeks to document how and where biodiversity offsetting is being applied in marine environments. We build upon a similar exercise undertaken by the Ecosystem Marketplace in 2010 and updated in 2011 that mapped global uptake of biodiversity markets but found little evidence of marine application [28,29]. 


\section{Methods}

This paper presents a snapshot as of December 2016 of the current application of biodiversity offsetting principles in a marine context. Relevant data were obtained through a systematic review of available web-based documents evidencing the application or inclusion of. biodiversity offset principles (see Table 1).Table 1 Information has been sourced from both academic and grey literature including relevant web-based material and media reports. In the review of academic literature, search terms outlined in electronic appendix 1 were used to interrogate the Scopus and Web of Science databases and web-based searches. Articles were screened and filtered against the principles presented in Table 1 and based on the content of their abstracts. A similar protocol was applied for a search of grey literature, using web-based search engines as a starting point. These systematic reviews were complemented by handsearching of literature and building on the country profiles within the Ecosystems Marketplace review [28,30]. The National Reports produced by the 156 coastal States Parties to the Convention on Biological Diversity (CBD) in addition to information available from the Organisation for Economic Co-operation and Development (OECD) and the Global Environment Facility (GEF) for all coastal nations were also reviewed.

The source material was limited to documents published in French, Spanish or English, with search terms based in English.

Information relating to the application of the key biodiversity offsetting principles (Table 1 ) has been gathered from the source material. A total of 124 documents were identified that provide evidence of the uptake and application of these principles (electronic appendix 2). Using these principles as criteria, evidence of the application of the mitigation hierarchy in addition to any other of the principles has been documented. The mitigation hierarchy is often promoted through environmental impact assessment (EIA) frameworks. Biodiversity offsetting builds on this and increases the rigour of its application through assessments of equivalence, additionality, continuity of biodiversity provision and compliance monitoring requirements (Table 1). Given the lack of available information relating to marine biodiversity offsets it is likely that such strategies are at varying stages of development or operating on an informal basis and are unlikely to incorporate all of the key principles. Accordingly, evidence of the uptake of any number of the key principles (in addition to the mitigation hierarchy) with explicit reference to supporting the use of marine biodiversity offsets is presented as an indication of emergent public policy or strategy. It is important to note that the approaches recorded here focus on ex ante approaches to environmental compensation and do not include requirements for rectifying unforeseen impacts or for rehabilitation of a site at the point of decommissioning.

This review does not analyse the information gathered concerning the effectiveness of offsets to avert biodiversity losses, or the extent to which widely accepted standards for best practice are integrated into the approaches identified [4]. The aim here is to identify instances where biodiversity offsetting principles are being applied in marine environments, and what form this takes. 


\section{Results}

The application or exploration of the potential to apply biodiversity offsetting principles in the marine environment was found in 45 countries. The mechanisms through which this is being undertaken vary - from being supported by established or emergent public policy at a national, supra- or sub-national level (Table 2) to being driven by various other means outside of public policy frameworks (Table 4). No evidence was found of the application of the principles in a marine context in Eastern Europe (electronic appendix 2). Evidence was found of application in marine contexts in North America, Australia, Europe, Africa, Asia, Latin America and Oceania. The type of mechanisms being used to apply marine biodiversity offsets by country are presented in Table 2 and Table 4.

\subsection{Marine biodiversity offsetting supported by public policy}

Public policy refers to existing and active policy specifically supporting the application of biodiversity offsets or an aim of NNL (or net benefit, net gain etc.), operational at a national (or supranational in the case of the EU) level and applicable to marine environments. National (or supranational) policies exist in the US, Canada, Australia, the EU, France, Germany and Colombia [23,24,31-39]. These policies support the application of the five principles essential to biodiversity offsetting success with the exception of with the exception of that in Colombia where detail relating to additionality was not found [38,39] (Table 1). Only one of these national policies, the Magnuson-Stevens Fishery Conservation and Management Act [40], has been developed specifically for marine application and with the exception of French, German and Colombian policy, all have application restricted to 'listed' marine habitats, species or protected areas.

Sub-national offsetting public policy has similar aims to that of national public policy but is relevant to specific sub-national political jurisdictions only (e.g. state level). Sub-national policy in South Africa precedes national policy and whilst terrestrial in focus does not preclude application in marine environments [41]. In the US and Australia sub-national policy has been developed for specific marine application of biodiversity offsets in the instance of impacts to eelgrass in California, fish habitat in New South Wales (NSW) and specifically for the Great Barrier Reef (GBR) in Queensland [42-45]. In Australia, sub-national policy supporting the application of biodiversity offsetting exists in five of its six states. Marine application for most sub-national offsetting policy in Australia relates to the protection of native vegetation which includes marine habitats such as seagrass. Outside of the marine specific policies of NSW and for the GBR, limited guidance is provided as to how impacts to marine vegetation should be addressed $[46,47]$. 
Table 2. Types of public policy mechanism identified as supporting the application of biodiversity offsetting principles in a marine context by country. *Sectoral offsetting policies identified stem from private standards, these examples are also included in Table 4. ${ }^{* *}$ US policies also apply to five US territories (see electronic appendix 2). ${ }^{* * *}$ Policies at a European Union (EU) level apply to all 23 coastal member states, however, a number of member states have moved ahead of the existing and tentatively emergent position. In addition, policy exists at an EU level that requires the comprehensive application of biodiversity offsetting principles but is restricted in application for impacts to designated sites only.

\begin{tabular}{|c|c|c|c|c|c|}
\hline & $\begin{array}{l}\text { National or } \\
\text { supranational } \\
\text { offsetting policy }\end{array}$ & $\begin{array}{l}\text { Sub-national } \\
\text { offsetting policy }\end{array}$ & $\begin{array}{l}\text { Emergent national } \\
\text { or supranational } \\
\text { offsetting policy }\end{array}$ & $\begin{array}{l}\text { National policy } \\
\text { applying partial } \\
\text { application of } \\
\text { offsetting principles }\end{array}$ & $\begin{array}{l}\text { Sectoral offsetting } \\
\text { policy* }\end{array}$ \\
\hline US** & $\checkmark$ & $\checkmark$ & & & \\
\hline Canada & $\checkmark$ & & & & \\
\hline Australia & $\checkmark$ & $\checkmark$ & & & \\
\hline $\begin{array}{l}\text { European Union } \\
(\mathrm{EU}) * * *\end{array}$ & $(\checkmark)$ & & $\checkmark$ (on hold) & & \\
\hline France & $\checkmark$ & & & & \\
\hline Germany & $\checkmark$ & & & & \\
\hline Netherlands & & & & $\checkmark$ & \\
\hline UK & & & $\checkmark$ (on hold) & & \\
\hline Liberia & & & & & $\checkmark$ \\
\hline Mozambique & & & & & $\checkmark$ \\
\hline South Africa & & $\checkmark$ & $\checkmark$ & & \\
\hline Argentina & & & & $\checkmark$ & \\
\hline Belize & & & $\checkmark$ & & \\
\hline Colombia & $\checkmark$ & & & & \\
\hline Peru & & & $\checkmark$ & & \\
\hline Korea & & & & $\checkmark$ & \\
\hline New Zealand & & $\checkmark$ & & & \\
\hline
\end{tabular}

Emergent national or supranational offsetting public policy refers to those countries where evidence of progression towards the development of a national policy (as defined in this paper) and uptake of biodiversity offsetting principles has been identified. In addition to existing sub-national policy, South Africa is exploring the development of national policies and options that are applicable to marine environments but limited information is available as to the detail of these discussions [41]. In Peru, uptake of a NNL goal is gaining momentum with offsetting policy and guidance being recently agreed for Andean environments, it is expected that the reach of this will expand to include marine environments in coming years [48]. Further, an EU initiated project, currently on hold, considers how an aim of NNL might extend beyond currently existing biodiversity protection legislation that is limited to key habitats and species $[49,50]$. The UK national position on biodiversity offsetting has been put on hold after an initial pilot project [51]. However, there was significant interest in its marine application and the potential opportunities to generate revenue for organisations such as the UK Crown Estate [52,53]. Despite this national position, the UK is still subject to the requirements of the EU Birds and Habitats Directives and a government-led project has been tendered relating to the identification of habitats to assist with the compensation requirements arising through the consenting processes for marine development [54]. 
Threats posed to the coastal marine environment have been directly addressed in Belize through the development of a marine biodiversity offset framework which is hoped to progress to a more formal state. This has been developed through a partnership with the Australia-Caribbean coral reef collaboration and the Belize Coastal Zone Management Authority and Institute [55]. This framework explicitly identifies the need for compliance and continuity however, the application of biodiversity offsetting principles in Belize is dependent on the compliance regime to be put in place to support implementation once adoption progresses beyond the current emergent status.

Sectoral offsetting public policy relates to the existence of policy developed for a specific sector (such as mining) that supports the application of biodiversity offsetting principles in a marine context. In both Liberia and Mozambique, the standards applied through this public policy have not been developed by government and relate directly to private standards which are considered in more detail in section 3.2 .

National public policy requiring partial application of offsetting principles relates to other national policies that do not explicitly reference biodiversity offsetting but support the application of a number of biodiversity offsetting principles. These principles go beyond the application of the mitigation hierarchy and seek to improve the success of compensatory action (Table 3). Legislation in the Netherlands extends the remit of the EU Birds and Habitats Directive to include some marine habitats and species of national importance. Whilst offsetting is not specifically referenced within this additional legislation, the need for equivalence and continuity of biodiversity to be considered when defining compensation arrangements is detailed [56]. The Korean Act on the Conservation and the Use of Biodiversity requires that a bond be held as security against compensation success and discussions have been held as to how a NNL policy could be introduced [57-63]. In Argentina legislation requires that impacts are remedied by the proponent causing biodiversity loss and establishes an environmental compensation fund as an option should restoration not be technically feasible [64]. 
Table 3. Biodiversity offsetting principles embedded within public policy frameworks. *The principles noted do not apply equally to all examples identified (see electronic appendix 2).

\begin{tabular}{|c|c|c|c|c|c|}
\hline & $\begin{array}{l}\text { National offsetting } \\
\text { policy }\end{array}$ & $\begin{array}{l}\text { Sub-national } \\
\text { offsetting policy }\end{array}$ & $\begin{array}{l}\text { Emergent national } \\
\text { offsetting policy* }\end{array}$ & $\begin{array}{l}\text { Sectoral offsetting } \\
\text { policy }\end{array}$ & $\begin{array}{l}\text { National policy } \\
\text { requiring partial } \\
\text { application of } \\
\text { offsetting principles* }\end{array}$ \\
\hline $\begin{array}{l}\text { Mitigation hierarchy } \\
\text { Offsets as a last resort through } \\
\text { avoiding, mitigating then } \\
\text { compensating (offsetting) residual } \\
\text { biodiversity impacts. }\end{array}$ & $x$ & $x$ & $x$ & $x$ & $x$ \\
\hline $\begin{array}{l}\text { Equivalence } \\
\text { Balance is sought between } \\
\text { biodiversity losses (impacts) and } \\
\text { gains (offsets). }\end{array}$ & $x$ & $x$ & $x$ & $x$ & $x$ \\
\hline $\begin{array}{l}\text { Additionality } \\
\text { offsets deliver benefits beyond } \\
\text { those that would occur in the } \\
\text { absence of the offset project. }\end{array}$ & $x$ & $x$ & $x$ & & \\
\hline $\begin{array}{l}\text { Continuity } \\
\text { Offsets deliver biodiversity benefits } \\
\text { from the point of biodiversity loss } \\
\text { and for the duration of impact. }\end{array}$ & $x$ & $x$ & $x$ & & \\
\hline $\begin{array}{l}\text { Compliance success } \\
\text { Implementation and success of } \\
\text { offset requirements should be } \\
\text { overseen by a third party or } \\
\text { regulator. }\end{array}$ & $x$ & $x$ & & $x$ & $x$ \\
\hline
\end{tabular}

\subsection{Offsetting mechanisms not stemming from public policy}

Evidence also exists for uptake of biodiversity offsetting principles in marine environments outside of public policy frameworks. These mechanisms are usually used at a project or an activity level and vary widely in extent and mode. Of the eight instances identified, six are directly associated with financial controls where a degree of compliance success is imparted through associated processes (Tables 4 and 5). The five types of mechanism promoting the application of biodiversity offsetting principles relating to finance include: (1) private standards levied by development banks such as the IFC $[65,66]$; (2) conservation funds promoting the pooling of funds for the strategic application of marine biodiversity offsets; (3) the application of a marine resource access charge [67]; (4) the research and development of biodiversity markets through the local-level fisheries management frameworks as being trialled in Chile [68]; and, (5) corporate standards. 
Table 4. The types of mechanism through which biodiversity offsetting principles are being applied in a marine context outside of policy frameworks. Application of these mechanisms is not always at a national level with many focussed at a sub-national or project level (Gabon, Yemen, PNG). *Private standards in Liberia and Mozambique have been incorporated into sectoral policy.

\begin{tabular}{|l|l|l|l|l|l|}
\hline & $\begin{array}{l}\text { Private } \\
\text { standards } \\
\text { (finance) }\end{array}$ & $\begin{array}{l}\text { Independent } \\
\text { conservation } \\
\text { fund }\end{array}$ & $\begin{array}{l}\text { Resource access } \\
\text { fee }\end{array}$ & $\begin{array}{l}\text { Biodiversity } \\
\text { markets }\end{array}$ & $\begin{array}{l}\text { Corporate } \\
\text { standards }\end{array}$ \\
\hline Liberia & $\checkmark^{*}$ & & & & \\
\hline Mozambique & $\checkmark^{*}$ & $\checkmark$ & & & $\checkmark$ \\
\hline Gabon & & & & & $\checkmark$ \\
\hline China & & & $\checkmark$ & & \\
\hline Yemen New & $\checkmark$ & & & & \\
\hline $\begin{array}{l}\text { Papua } \\
\text { Guinea (PNG) }\end{array}$ & & & & & $\checkmark$ \\
\hline Chile & & & & & \\
\hline
\end{tabular}

The final type of mechanism identified relates to the practical application of corporate standards, for which evidence has been found at a project rather than national level. There has been an increased recognition of the need to address the environmental impacts of corporations as major contributors to current trends of declining biodiversity [69]. In response, a growing number of corporations have identified or articulated a business case for improving their environmental practices - e.g. in order to secure access to essential environmental assets, and to gain a social licence to operate and use these resources $[8,69]$. One example of this is Tullow Oil's joint project with the Wildlife Conservation Society (WCS) in Gabon which seeks to improve marine ecological knowledge to improve the application of the mitigation hierarchy in offshore environments $[28,70,71]$. 
For the purposes of this review the private standards imposed by the International Finance Corporation (IFC) and other development banks have been considered separate to corporate standards adopted by private industry. Finance provided through the IFC and other development banks requires recipient adherence to a number of biodiversity offsetting principles $[65,72]$. For example, the IFC's Performance Standard 6 specifically requires private sector clients receiving investment to implement a policy of NNL which is then enforced by the financial body subject to the conditions of agreement. These standards are commonly applied at a project level and evidence of this occurring in a marine context has been observed in Papua New Guinea (PNG) (Table 4.). Private standards have also influenced uptake of biodiversity offsetting principles through public policy. Evidence of where this has occurred and is applicable to marine environments has been identified in Liberia and Mozambique. In Liberia, sectoral policy exists for the mining industry outlining requirements to follow the IFC's Performance Standard 6 [73,74]. In Mozambique, Article 23 of the Petroleum Laws in Mozambique require operations to adhere to "internationally accepted standards" in relation to inevitable ecological damage and the associated mitigation of impacts [75]. Whilst the reference to biodiversity offsetting is not explicit, this implies the need to meet common standards such as that outlined in the IFC's Performance Standard 6 [65].

Table 5. Biodiversity offsetting principles applied in a marine context through mechanisms outside of policy frameworks.

\begin{tabular}{|l|l|l|l|l|l|}
\hline & $\begin{array}{l}\text { Private } \\
\text { standards }\end{array}$ & $\begin{array}{l}\text { Conservation } \\
\text { fund }\end{array}$ & $\begin{array}{l}\text { Resource } \\
\text { access fee }\end{array}$ & $\begin{array}{l}\text { Biodiversity } \\
\text { markets }\end{array}$ & $\begin{array}{l}\text { Corporate } \\
\text { standards }\end{array}$ \\
\hline $\begin{array}{l}\text { Mitigation hierarchy } \\
\text { Offsets as a last resort through } \\
\text { avoiding, mitigating then } \\
\text { compensating (offsetting) residual } \\
\text { biodiversity impacts. }\end{array}$ & $\times$ & & & $\times$ \\
\hline $\begin{array}{l}\text { Equivalence } \\
\text { Balance is sought between } \\
\text { biodiversity losses (impacts) and } \\
\text { gains (offsets). }\end{array}$ & $\times$ & & & $\times$ & $\times$ \\
\hline $\begin{array}{l}\text { Additionality } \\
\text { offsets deliver benefits beyond } \\
\text { those that would occur in the } \\
\text { absence of the offset project. }\end{array}$ & & & & & \\
\hline $\begin{array}{l}\text { Continuity } \\
\text { Offsets deliver biodiversity benefits } \\
\text { from the point of biodiversity loss } \\
\text { and for the duration of impact. }\end{array}$ & & $\times$ & $\times$ & $\times$ & \\
\hline $\begin{array}{l}\text { Compliance success } \\
\text { Implementation and success of } \\
\text { offset requirements should be } \\
\text { overseen by a third party or } \\
\text { regulator. }\end{array}$ & $\times$ & $\times$ & & & \\
\hline
\end{tabular}




\section{Discussion}

\subsection{Biodiversity offsetting in a marine context}

Biodiversity offsetting policy has largely been developed for terrestrial application [28,29]. Our review indicates that translation and application of this policy to marine environments has commonly taken place with little consideration of the challenges specific to these environments. The guiding principles for the success of biodiversity offsets in marine environments are almost identical to those required in terrestrial environments [14,21]. However even in terrestrial environments, success of the approach to counter biodiversity losses and the application of these principles has proved to be challenging and there are concerns that it's misuse may be contributing to declining trends of biodiversity [76]. The difficulties faced in the terrestrial environment include; the accounting of biodiversity (often across biodiversity types) to ensure that an aim of NNL is met; our ability to restore ecological components and habitats [3]; those relating to compliance, such as the appropriate application of the mitigation hierarchy and post-consent monitoring; and the avoidance of the perverse application of the approach [77]. These challenges all apply to the marine application of biodiversity offsetting but are further exacerbated by three key factors; (1) the high level of uncertainty within marine impact assessment owing to the highly variable and connected nature of the environment [15,19]; (2) the limited evidence of ecological restoration success in a marine context [15]; (3) the diffuse, complicated and at times remote governance arrangements managing the resource [21].

\subsection{Marine offsets required by public policy}

Public policy relating specifically to offsetting and its application in marine environments was found to exist at a national (or supranational) level or a sub-national level in 30 countries and at a developmental stage in three countries (Table 1). In each of these countries impacts to marine habitats and species identified as ecologically important are required to be offset in line with the five key principles for biodiversity offsetting success (Tables 1 and 3). Public policy under development cannot incorporate measures for compliance success given that consenting regimes are to be established. All policy identified applies directly to marine environmental impacts and seeks to protect against losses of marine biodiversity. However, translation of this policy has only been considered in detail in relation to a very limited range of ecological components, eg. - the highly spatially managed GBR $[45,80]$ and fish habitat $[40,43,44]$. Little guidance is available relating to the consideration of mobile species such as seabirds and marine mammals or wider issues such as the social values attributed to marine parks. The uncertainty in impact prediction and ecological restoration is acknowledged in these 'marinespecific' policies with greater flexibility allowed in the application of the principles. For example, the definition of equivalence in some cases is applied much more loosely to allow for interpretation beyond 'like for like' replacement of habitat (electronic appendix 2). In situations where rehabilitation of habitat is difficult, as is the case with most fish habitat [43], metrics are applied to calculate a financial equivalent to be applied by the regulator to create biodiversity gains to equal losses. 


\subsection{Uptake outside of public policy}

Private standards formally regulate biodiversity offsetting on a project by project basis through financial agreements and these can apply to projects leading to impacts on marine biodiversity. Despite private standards commonly applying at a project level, there is evidence of their incorporation into public policy. An example of this is the Liberian Mining Act which specifically references the private standards of the IFC relating to biodiversity offsetting [65,73]. Biodiversity offsetting requirements from these sectoral public policies stem from the existence of these privately developed standards and have not been developed by government.

In addition to the more formally regulated private standards, other less formal approaches are driving the application of biodiversity offsetting in marine environments. These mechanisms are usually used at a project or activity level in the absence of national or sub-national policies and in most cases are applicable to marine environments but have not been developed specifically for this purpose. The exception to this is the work being piloted in Chile to develop biodiversity markets through local fisheries-based management where issues relating to tenure of spatial areas of the fishery are overcome through the application of territorial user rights for fisheries [68]. The authors of the study outlining the progress of this pilot cite the need to develop new conservation instruments to support underfunded international targets such as those under the Convention on Biological Diversity as drivers for this work [81]. Other indications exists that marine biodiversity offsetting is being used to raise revenue where central funding does not exist or is insufficient to meet wide conservation commitments, such as in Mozambique where the development of a conservation trust fund specifically states the "consolidation of the national Protected Areas system" as part of its mission [82]. It is widely accepted that funding for marine conservation is not sufficient to support the activity required to protect marine environmental resources [83]. However, cautious management is required if offsets are to be used in this manner to ensure true additionality and to avoid 'cost-shifting' and the displacement of existing or future sources of marine conservation finance $[77,84]$. 
Corporate standards are another mechanism driving uptake of biodiversity offsetting principles in the marine environment. An increased appreciation of the business relevance of environmental impacts and the maintenance of a social licence to operate has led to a recent increase in uptake of corporate goals or standards relating to biodiversity [69]. Some of these standards relate specifically to a company-level commitment to NNL of biodiversity [69]. However, despite evidence of marine application at a project level being available no evidence was found of strategic policy level consideration of what might be required for successful application in marine environments. Corporate standards are not necessarily subject to third party oversight and no information was found that allowed for an assessment of the influence or success of such aims. In contrast, private standards such as those required by the IFC and other sources of development finance are subject to third party oversight. This increases the rigour of environmental management in countries that do not currently have marine biodiversity offsetting requirements incorporated into public policy. For those mechanisms being applied outside of public policy compliance is the principle most commonly addressed. Independent third party oversight (private standards), the upfront payment into a conservation fund or of a resource access fee, or the purchase of credits from a biodiversity bank (biodiversity markets) increases the likelihood of compensation taking place. However, ensuring compliance does not provide the assurance that associated action will lead to a balance of marine biodiversity losses and gains that other principles such as equivalence, additionality and continuity could.

\section{Conclusion}

This review presents a first attempt at documenting the current global status of application of biodiversity offsetting in a marine context. Results highlight that the approach is being applied in diverse policy contexts and the principles identified as essential for offsetting success offsetting success are being subject to both partial and comprehensive adoption. National biodiversity offsetting policies applicable to the marine environment were identified in six countries with at least 27 others actively pursuing similar approaches. However, existing policy has not, with the exception of a very low number of sub-national and fisheries specific policies, been developed specifically for marine application. Furthermore, little detail is available as to how the key challenges presented by the marine environment might be addressed in existing non-marine specific biodiversity offsetting policy. Where frameworks have been developed specifically for marine application a common suggestion appears to be pooling financial contributions to apply to strategic projects for wider biodiversity benefit. This review does not include an analysis of the success of the policies and other approaches in achieving or contributing to an aim of NNL of biodiversity. Further understanding of how the approach is being used to manage biodiversity losses is required to better understand the risks posed by the application of biodiversity offsets in marine environments. 


\section{References}

[1] MEA, Ecosystems and Human and Well Being: Synthesis, Washington, DC., 2005.

[2] UNEP, Global environment outlook 5: Environment for the future we want, 2012. doi:10.2307/2807995.

[3] J.W. Bull, K.B. Suttle, A. Gordon, N.J. Singh, E.J. Milner-Gulland, Biodiversity offsets in theory and practice, Oryx. 47 (2013) 369-380.

[4] Business and Biodiversity Offsets Programme (BBOP), Standard on Biodiversity Offsets, Washington, D.C., 2012. http://bbop.forest-trends.org/guidelines/Standard.pdf.

[5] B.A. McKenney, J.M. Kiesecker, Policy development for biodiversity offsets: a review of offset frameworks, Environ. Manage. 45 (2010) 165-176.

[6] T.A. Gardner, A. Von Hase, S. Brownlie, J.M.M. Ekstrom, J.D. Pilgrim, C.E. Savy, R.T.T. Stephens, J. Treweek, G.T. Ussher, G. Ward, K. Ten Kate, Biodiversity offsets and the challenge of achieving no net loss., Conserv. Biol. 27 (2013) 1254-64. doi:10.1111/cobi.12118.

[7] J. Wilkinson, In-lieu fee mitigation: coming into compliance with the new Compensatory Mitigation Rule, Wetl. Ecol. Manag. 17 (2008) 53-70. doi:10.1007/s11273-008-9120-8.

[8] C. Calvet, O. Guillaume, N. Claude, Tracking the origins and development of biodiversity offsetting in academic research and its implications for conservation: A review, Biol. Conserv. (2015). doi:10.1016/j.biocon.2015.08.036.

[9] P. Gibbons, D.B. Lindenmayer, Offsets for land clearing: No net loss or the tail wagging the dog?, Ecol. Manag. Restor. 8 (2007) 26-31. doi:10.1111/j.1442-8903.2007.00328.x.

[10] M.E. Kentula, Perspectives on setting success criteria for wetland restoration, Ecol. Eng. 15 (2000) 199-209. doi:10.1016/S0925-8574(00)00076-8.

[11] M. Maron, J.W. Bull, M.C. Evans, A. Gordon, Locking in loss: Baselines of decline in Australian biodiversity offset policies, Biol. Conserv. (2015). doi:10.1016/j.biocon.2015.05.017.

[12] F. Quétier, S. Lavorel, Assessing ecological equivalence in biodiversity offset schemes: key issues and solutions, Biol. Conserv. 144 (2011) 2991-2999.

[13] J.W. Bull, M.J. Hardy, A. Moilanen, A. Gordon, Categories of flexibility in biodiversity offsetting, and their implications for conservation, Biol. Conserv. (2015). doi:10.1016/j.biocon.2015.08.003.

[14] UNEP-WCMC, Marine No Net Loss: A feasibility assessment of implementing no net loss of biodiversity in the sea, Cambridge, 2016.

[15] A. Bas, C. Jacob, J. Hay, S. Pioch, S. Thorin, Improving marine biodiversity offsetting: A proposed methodology for better assessing losses and gains., J. Environ. Manage. 175 (2016) 46-59. doi:10.1016/j.jenvman.2016.03.027.

[16] B.S. Halpern, M. Frazier, J. Potapenko, K.S. Casey, K. Koenig, C. Longo, J.S. Lowndes, R.C. 
Rockwood, E.R. Selig, K.A. Selkoe, S. Walbridge, Spatial and temporal changes in cumulative human impacts on the world's ocean, Nat. Commun. 6 (2015) 7615. doi:10.1038/ncomms8615.

[17] European Commission, Blue Growth - Opportunities for marine and maritime sustainable growth, Luxembourg, 2012. doi:10.2771/43949.

[18] OECD, The Ocean Economy in 2030, OECD Publishing, Paris, 2016. doi:10.1787/9789264251724-en.

[19] L. Crowder, E. Norse, Essential ecological insights for marine ecosystem-based management and marine spatial planning, Mar. Policy. $32 \quad$ (2008) 772-778. doi:10.1016/j.marpol.2008.03.012.

[20] F. Douvere, F. Maes, A. Vanhulle, J. Schrijvers, The role of marine spatial planning in sea use management: The Belgian case, Mar. Policy. 31 (2007) 182-191. doi:10.1016/j.marpol.2006.07.003.

[21] M. Bos, R.L. Pressey, N. Stoeckl, Effective marine offsets for the Great Barrier Reef World Heritage Area, Environ. Sci. Policy. 42 (2014) 1-15. doi:10.1016/j.envsci.2014.05.002.

[22] A.-C. Vaissière, H. Levrel, S. Pioch, A. Carlier, Biodiversity offsets for offshore wind farm projects: The current situation in Europe, Mar. Policy. 48 (2014) 172-183. doi:10.1016/j.marpol.2014.03.023.

[23] US EPA, Summary of the Clean Water Act, (2015). http://www.epa.gov/lawsregulations/summary-clean-water-act (accessed December 15, 2015).

[24] US EPA, Summary of the Endangered Species Act, (2015). http://www.epa.gov/lawsregulations/summary-endangered-species-act (accessed December 16, 2015).

[25] Minister of Justice, Fisheries Act, Government of Canada, 1985. http://laws-lois.justice.gc.ca.

[26] Department of the Environment and Energy, Environment Protection and Biodiversity Conservation Act 1999 (EPBC Act), Australian Government, Canberra, 1999. https://www.legislation.gov.au/Details/C2016C00777 (accessed December 16, 2015).

[27] C. Jacob, S. Pioch, S. Thorin, The effectiveness of the mitigation hierarchy in environmental impact studies on marine ecosystems: A case study in France, Environ. Impact Assess. Rev. 60 (2016) 83-98. doi:10.1016/j.eiar.2016.04.001.

[28] B. Madsen, N. Carroll, K.K. Moore Brands, G. Bennett, State of Biodiversity Markets: Offset and Compensation Programs Worldwide I UNDP, Washington, DC., 2010. http://www.undp.org/content/undp/en/home/librarypage/environmentenergy/ecosystems_and_biodiversity/state-of-biodiversity-markets-offset-andcompensation-programs-worldwide/ (accessed April 17, 2014).

[29] B. Madsen, N. Carroll, D. Kandy, G. Bennett, 2011 Update: State of Biodiversity Markets, Washington, DC., 2011. http://www.ecosystemmarketplace.com/reports/2011_update.sbdm.

[30] R. Armstrong, N. Jackson, J. Doyle, E. Waters, F. Howes, It's in your hands: The value of 
handsearching in conducting systematic reviews of public health interventions, J. Public Health (Bangkok). 27 (2005) 388-391. doi:10.1093/pubmed/fdi056.

[31] DoD, EPA, Memorandum of Agreement Between the Environmental Protection Agency and the Department of the Army Concerning the Determination of Mitigation Under the Clean Water Act Section 404(b)(1) Guidelines, 1990.

[32] Australian Government, Environment Protection and Biodiversity Conservation Act 1999: Environmental Offsets Policy, Departement of Sustainability, Environment, Water, Population and Communities, Canberra, 2012.

[33] European Commission, Directive 2009/147/EC of the European Parliament and of the Council on the conservation of wild birds, European Commission, 2010. http://www.ecolex.org/ecolex/ledge/view/RecordDetails;jsessionid=90B0F1A51EC0A343514 1652323F905BE?id=LEX-FAOC092236\&index=documents.

[34] European Commission, Council Directive 92/43/EEC of 21 May 1992 on the conservation of natural habitats and of wild fauna and flora, European Commission, 1992.

[35] MEDDE, Doctrine relative a la sequence eviter, reduire et compenser les impacts sur le milieu naturel, Ministere de I'Ecologie, du Developpement Durable et de l'Energie, Paris, France, 2012.

[36] MEDDE, Lignes directrices nationales sur la sequence eviter, reduire et compenser les impacts sur les milieux naturels., Ministere de l'Ecologie, du Developpement Durable et de l'Energie, Paris, France, 2013.

[37] Federal Ministry for the Environment Nature Conservation and Nuclear Safety, Act on Nature Conservation and Landscape Management (Federal Nature Conservation Act - BNatSchG) of 29 July 2009, 2010. www.bmub.bund.de/N46170-1/.

[38] Ministerio de Ambiente y Desarrollo Sostenible (MADS), Resolution 1517, 31 Aug 2012 "Por la cual se adopta el Manual para la Asignación de Compensaciones por Pérdida de Biodiversidad," 2012.

http://www.anla.gov.co/documentos/normativa/13992_Resolucion_1517_2012_Adopta_ma nual_compensac_perdida_biodiversidad.pdf.

[39] Ministerio de Ambiente y Desarrollo Sostenible (MADS), Manual Para La Asignacion de Compensaciones por Perdida de Biodiversidad, ANLA, 2012.

[40] NOAA, Magnuson-Stevens Fishery Conservation and Management Act, U.S. Government, 2007. http://www.nmfs.noaa.gov/sfa/laws_policies/msa/ (accessed December 8, 2016).

[41] N. Jenner, Z. Balmforth, Biodiversity offsets: Lessons learnt from policy and practice. Country summary report: South Africa, Cambridge, 2015. doi:www.fauna-flora.org.

[42] NOAA Fisheries: West Coast Region, California Eelgrass Mitigation Policy and Implementing Guidelines, 2014. 
[43] S. Fairfull, Fisheries NSW Policy and guidelines for fish habitat conservation and management, Wollongbar, 2013. doi:ISBN 9781742562834.

[44] Queensland Government, Queensland Environmental Offsets Policy (version 1.2), Biodiversity Integration and Offsets, Department of Environment and Heritage Protection, Australia, 2016.

[45] G. Dutson, L. Bennun, M. Maron, J. Brodie, M. Bos, J. Waterhouse, Determination of suitable financial contributions as offsets within the Reef Trust, Cambridge, 2015.

[46] Department of Environment Water and Natural Resources, Policy for Significant Environmental Benefit, Adelaide, South Australia, 2015. doi:10.1002/ejoc.201200111.

[47] Victoria State Government, Victoria Planning Provisions, Minister for Planning, Melbourne, Victoria, Australia, 2016.

[48] E. Pilla, Towards the Development of Metrics for No Net Loss of Biodiversity in Peru, Washington, D.C., 2014.

[49] European Commission, Guidance document on Article 6 (4) of the "Habitats Directive" 92/43/EEC, 2012.

[50] D. McGillivray, Compensating Biodiversity Loss: The EU Commission's Approach to Compensation under Article 6 of the Habitats Directive, J. Environ. Law. 24 (2012) 417-450.

[51] DEFRA, Biodiversity Offsetting in England: Green paper, DEFRA, 2013.

[52] D. Cook, N. Clay, Marine Biodiversity Offsetting and Habitat Banking Feasibility Study, London, 2013.

[53] I. Dickie, L. McAleese, B. Pearce, J. Treweek, Marine Biodiversity Offsetting - UK Scoping Study, London, 2013.

[54] MMO, The location, condition and features of significant sites for habitat creation or restoration - $\quad$ Publications - GOV.UK, (2016). https://www.gov.uk/government/publications/the-location-condition-and-features-ofsignificant-sites-for-habitat-creation-or-restoration (accessed January 5, 2017).

[55] Belize Coastal Zone Management Authority \& Institute and Australia-Caribbean Coral Reef Collaboration, Marine and coastal biodiversity offsets framework for Belize, Townsville, 2014. http://climateandreefs.org/biodiversity-offsets/.

[56] G. Tucker, B. Allen, M. Conway, I. Dickie, K. Hart, M. Rayment, C. Schulp, A. van Teeffelen, Policy options for an EU no net loss initiative. Report to the European Commission, London, 2014.

[57] Ministry of Land Transport and Maritime Affairs - Marine Environmental Policy Division, Marine Environment Management Act (English translation), Government of South Korea, 2009.

[58] Ministry of Environment of the Republic of Korea, The Fifth National Report ot the Convention on Biological Diversity, Sejong Special Self-Governing City, Korea, 2014. 
[59] OECD, OECD environmental performance reviews: Korea, Paris, France, 2006.

[60] S.G. Kim, The evolution of coastal wetland policy in developed countries and Korea, Ocean Coast. Manag. 53 (2010) 562-569. doi:10.1016/j.ocecoaman.2010.06.017.

[61] J.-Y. Lee, Current status, policies and challenges for Marine Protected Areas in Korea, (2013). http://www.neaspec.org/sites/default/files/3-3_Republic_of_Korea.pdf (accessed December 18, 2015).

[62] Ministry of Environment of the Republic of Korea, Korea's National Biodiversity Strategy 20142018, Sejong Special Self-Governing City, Korea, 2014.

[63] Ministry of Economic Affairs, Convention on Biological Diversity - Fifth National Report of the Kingdom of the Netherlands, The Hague, 2014. http://www.cbd.int/default.shtml.

[64] Republic of Argentina, Ley General del Ambiente, Buenos Aires, 2002.

[65] IFC, Performance Standard 6: Biodiversity Conservation and Sustainable Management of Living Natural Resources, 2012. www.ifc.org.

[66] Equator Principles Association, The Equator Principles, 2013. http://www.equatorprinciples.com.

[67] H. Rao, C. Lin, H. Kong, D. Jin, B. Peng, Ecological damage compensation for coastal sea area uses, Ecol. Indic. 38 (2014) 149-158. doi:10.1016/j.ecolind.2013.11.001.

[68] S. Gelcich, C.J. Donlan, Incentivizing biodiversity conservation in artisanal fishing communities through territorial user rights and business model innovation, Conserv. Biol. 29 (2015) 10761085. doi:10.1111/cobi.12477.

[69] H.J. Rainey, E.H.B. Pollard, G. Dutson, J.M.M. Ekstrom, S.R. Livingstone, H.J. Temple, J.D. Pilgrim, A review of corporate goals of No Net Loss and Net Positive Impact on biodiversity, Oryx. (2014) 1-7. doi:10.1017/S0030605313001476.

[70] Tullow Oil and WCS initiate a vast research project on the marine environment, Le Gabon.org. (2012). http://www.en.legabon.org/news/1241/tullow-oil-and-wcs-initiate-vast-researchproject-marine-environment (accessed August 20, 2015).

[71] Tullow Oil, Biodiversity Research with the Wildlife Conservation Society, 2013. (n.d.). http://www.tullowoil.com/media/case-studies/biodiversity-research-with-the-wildlifeconservation-society (accessed August 20, 2015).

[72] A. Villarroya, A.C. Barros, J. Kiesecker, Policy development for environmental licensing and biodiversity offsets in latin america., PLoS One. 9 (2014) e107144. doi:10.1371/journal.pone.0107144.

[73] Ministry of Foreign Affairs, An Act Adopting the Environment Protection and Management Law of the Republic of Liberia, Environmental Protection Agency, Monrovia, Liberia, 2002.

[74] S. Johnson, A national biodiversity offset scheme : a road map for Liberia's mining sector, 2015. 
http://documents.worldbank.org/curated/en/2015/04/24418254/national-biodiversityoffset-scheme-road-map-liberia's-mining-sector.

[75] Republic of Mozambique, Petroleum law no. 21/2014, dated 18th August, 2014.

[76] M. Maron, A. Gordon, B.G. Mackey, H.P. Possingham, J.E.M. Watson, Interactions between biodiversity offsets and protected area commitments: Avoiding perverse outcomes, Conserv. Lett. (2015) n/a-n/a. doi:10.1111/conl.12222.

[77] M. Maron, A. Gordon, B.G. Mackey, H.P. Possingham, J.E.M. Watson, Conservation: Stop misuse of biodiversity offsets, Nature. 523 (2015) 401-403. doi:10.1038/523401a.

[78] S. de Bie, B. van Dessel, Compensation For Biodiversity Loss - Advice to the Netherlands' Taskforce on Biodiversity and Natural Resource, Klarenbeek, 2011.

[79] M. Conway, M. Rayment, A. White, S. Berman, Exploring potential demand for and supply of habitat banking in the EU and appropriate design elements for a habitat banking scheme, London, 2013.

[80] M. Maron, M. Walsh, N. Shumway, J. Brodie, Reef Trust Offsets Calculator, Brisbane, Queensland, Australia, 2016.

[81] CBD, Quick guide to the Aichi Biodiversity Targets: Target 11, (2013). https://www.cbd.int/doc/strategic-plan/targets/T11-quick-guide-en.pdf (accessed March 29, 2017).

[82] BIOFUND, Biofund, (2016). http://www.biofund.org.mz/en/ (accessed May 11, 2016).

[83] M. Bos, R.L. Pressey, N. Stoeckl, Marine conservation finance: The need for and scope of an

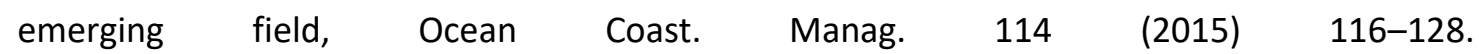
doi:10.1016/j.ocecoaman.2015.06.021.

[84] J.D. Pilgrim, L. Bennun, Will Biodiversity Offsets Save or Sink Protected Areas?, Conserv. Lett. 7 (2014) 423-424. doi:10.1111/conl.12145. 


\section{Electronic Appendix 1.}

Search terms applied to Scopus and Web of Science databases

(( marine OR "fish habitat") AND ( offset* OR biodiversity offset* OR compensat*)) 
Electronic appendix 2.

Mode of uptake of biodiversity offsetting principles in the marine environment by country ${ }^{1}$

\begin{tabular}{|c|c|c|c|c|c|c|c|c|c|c|c|c|}
\hline \multirow[b]{2}{*}{ Country } & \multicolumn{2}{|c|}{ Offset mechanism } & \multirow[b]{2}{*}{ Aim } & \multirow[b]{2}{*}{$\begin{array}{l}\text { Marine } \\
\text { specific }\end{array}$} & \multirow{2}{*}{$\begin{array}{l}\text { Marine relevance if } \\
\text { not specific }\end{array}$} & \multirow{2}{*}{$\begin{array}{l}\text { Instrument } \\
\text { used }\end{array}$} & \multirow{2}{*}{$\begin{array}{l}\text { Mitigation } \\
\text { hierarchy }\end{array}$} & \multirow[b]{2}{*}{ Equivalence } & \multirow[b]{2}{*}{ Additionality } & \multirow[b]{2}{*}{ Continuity } & \multirow[b]{2}{*}{$\begin{array}{l}\text { Compliance } \\
\text { success }\end{array}$} & \multirow[b]{2}{*}{ References } \\
\hline & Type & Detail & & & & & & & & & & \\
\hline \multicolumn{13}{|c|}{ North America } \\
\hline US & $\begin{array}{l}\text { National } \\
\text { offsetting policy }\end{array}$ & Clean Water Act (CWA) & "no overall net loss" [1] & No & $\begin{array}{l}\text { Applies to special } \\
\text { aquatic sites } \\
\text { including sanctuaries } \\
\text { and refuges, } \\
\text { wetlands, mud flats, } \\
\text { vegetated shallows } \\
\text { and coral reefs }\end{array}$ & $\begin{array}{l}\text { Bank, ILF, } \\
\text { PRM }\end{array}$ & Yes & 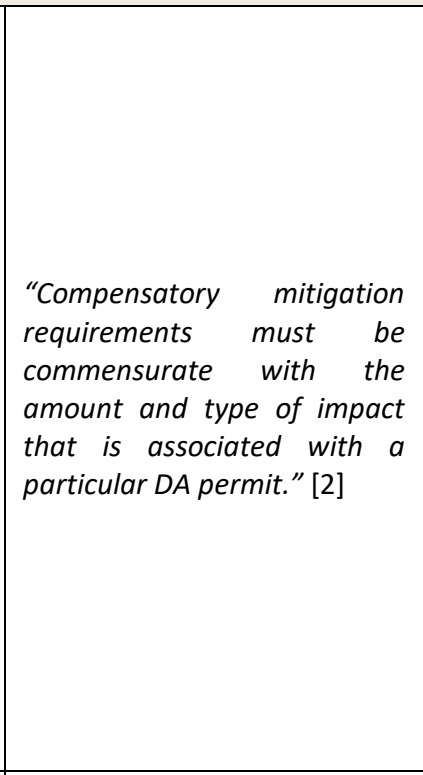 & $\begin{array}{l}\text { "Credits for compensatory } \\
\text { mitigation projects on public } \\
\text { land must be based solely on } \\
\text { aquatic resource functions } \\
\text { provided by the compensatory } \\
\text { mitigation project, over and } \\
\text { above those provided by public } \\
\text { programs already planned or in } \\
\text { place." [2] }\end{array}$ & $\begin{array}{l}\text { "Temporal loss is the time lag } \\
\text { between the loss of aquatic } \\
\text { resource functions caused by } \\
\text { the permitted impacts and the } \\
\text { replacement of aquatic } \\
\text { resource functions at the } \\
\text { compensatory mitigation site. } \\
\text { Higher compensation ratios } \\
\text { may be required to compensate } \\
\text { for temporal loss." [2] } \\
\text { "The district engineer shall } \\
\text { require sufficient financial } \\
\text { assurances to ensure a high } \\
\text { level of confidence that the } \\
\text { compensatory mitigation } \\
\text { project will be successully } \\
\text { completed, in accordance with } \\
\text { applicable performance } \\
\text { standards." [2] }\end{array}$ & $\begin{array}{l}\text { managed } \\
\text { through } \\
\text { planning } \\
\text { conditions }\end{array}$ & {$[1-8]$} \\
\hline US & $\begin{array}{l}\text { National } \\
\text { offsetting policy }\end{array}$ & $\begin{array}{l}\text { Endangered Species Act } \\
1973 \text { (ESA) }\end{array}$ & $\begin{array}{l}\text { Application of species } \\
\text { recovery goal. }\end{array}$ & No & $\begin{array}{l}\text { List of endangered } \\
\text { species includes } 125 \\
\text { marine species. }\end{array}$ & $\begin{array}{l}\text { Bank, ILF, } \\
\text { PRM }\end{array}$ & Yes & $\begin{array}{l}\text { "ensure that any action } \\
\text { authorized, funded, or carried } \\
\text { out by the agency is not likely } \\
\text { to jeopardize the continued } \\
\text { existence of any listed species } \\
\text { or result in the destruction or } \\
\text { adverse modification of } \\
\text { habitat that has been } \\
\text { designated as critical for the } \\
\text { species" [9] } \\
\text { "minimize and mitigate } \\
\text { adverse effects" [of incidental } \\
\text { take of species] [9] }\end{array}$ & & & $\begin{array}{l}\text { managed } \\
\text { through } \\
\text { planning } \\
\text { conditions }\end{array}$ & {$[9-13]$} \\
\hline US & $\begin{array}{l}\text { National } \\
\text { offsetting policy }\end{array}$ & $\begin{array}{l}\text { Magnuson-Stevens } \\
\text { Fishery Conservation and } \\
\text { Management Act }\end{array}$ & $\begin{array}{l}\text { "conservation and } \\
\text { enhancement of essential } \\
\text { fish habitat" [14] }\end{array}$ & Yes & & & Yes & & & & $\begin{array}{l}\text { managed } \\
\text { through } \\
\text { planning } \\
\text { conditions }\end{array}$ & {$[14,15]$} \\
\hline
\end{tabular}




\begin{tabular}{|c|c|c|c|c|c|c|c|c|c|c|c|c|}
\hline \multirow[b]{2}{*}{ Country } & \multicolumn{2}{|l|}{ Offset mechanism } & \multirow[b]{2}{*}{ Aim } & \multirow[b]{2}{*}{$\begin{array}{l}\text { Marine } \\
\text { specific }\end{array}$} & \multirow[b]{2}{*}{$\begin{array}{l}\text { Marine relevance if } \\
\text { not specific }\end{array}$} & \multirow[b]{2}{*}{$\begin{array}{l}\text { Instrument } \\
\text { used }\end{array}$} & \multirow[b]{2}{*}{$\begin{array}{l}\text { Mitigation } \\
\text { hierarchy }\end{array}$} & \multirow[b]{2}{*}{ Equivalence } & \multirow[b]{2}{*}{ Additionality } & \multirow[b]{2}{*}{ Continuity } & \multirow[b]{2}{*}{$\begin{array}{l}\text { Compliance } \\
\text { success }\end{array}$} & \multirow[b]{2}{*}{ References } \\
\hline & Type & Detail & & & & & & & & & & \\
\hline us & $\begin{array}{l}\text { Sub-national } \\
\text { policy }\end{array}$ & $\begin{array}{lr}\text { National Marine } & \text { Fisheries } \\
\text { Service's } & \text { (NMFS) } \\
\text { Californiar } & \text { Eelgrass } \\
\text { Mitigation Policy } & \end{array}$ & $\begin{array}{l}\text { "no net loss of eelgrass } \\
\text { habitat function in } \\
\text { California" [16] }\end{array}$ & Yes & & $\begin{array}{l}\text { Bank, ILF, } \\
\text { PRM }\end{array}$ & Yes & $\begin{array}{l}\text { "It is NMFS' policy to } \\
\text { recommend no net loss of } \\
\text { eelgrass habitat function in } \\
\text { California." [16] } \\
\text { "I is the intent of this policy to } \\
\text { ensure that there is no loss } \\
\text { associated with delays in } \\
\text { establishing compensatory } \\
\text { mitigation. This should be } \\
\text { accomplished by creating a } \\
\text { greater amount of eelgrass } \\
\text { than is lost, if the mitigation is } \\
\text { performed } \\
\text { contemporaneously or after } \\
\text { the impacts occur." [16] }\end{array}$ & $\begin{array}{l}\text { "only with the approval of } \\
\text { NMFS and other appropriate } \\
\text { resource agencies and subject } \\
\text { to the caveats below, eelgrass } \\
\text { habitat expansion resulting } \\
\text { from project activities, and that } \\
\text { otherwise would not have } \\
\text { occurred, has the potential to } \\
\text { be considered for future } \\
\text { mitigation needs." [16] }\end{array}$ & $\begin{array}{l}\text { "Delays in eelgrass mitigation } \\
\text { result in delarys in ultimate } \\
\text { reestablishment of eelgrass } \\
\text { habitat functions, increasing } \\
\text { the duration and magnitude of } \\
\text { project impacts to eelgrass. To } \\
\text { offset loss of eelgrass habitat } \\
\text { function that accumulates } \\
\text { through delay, an increase in } \\
\text { successuleelgrass mitigation is } \\
\text { needed to achieve the same } \\
\text { compensatory habitat function. } \\
\text { Because habitat function is } \\
\text { accumulated over time once } \\
\text { the mitigation habitat is in } \\
\text { place, the longer the delay in } \\
\text { initiation of mitigation, the } \\
\text { greater the additional habitat } \\
\text { area needed (i.e., mitigation } \\
\text { ratio increasingly greater than } \\
1.2: 1) \text { to offset losses." [16] }\end{array}$ & $\begin{array}{l}\text { managed } \\
\text { through } \\
\text { planning } \\
\text { conditions }\end{array}$ & [16] \\
\hline Canada & $\begin{array}{l}\text { National } \\
\text { offsetting policy }\end{array}$ & $\begin{array}{lll}\text { Fisheries } & & \text { Act } \\
-\quad \text { Policy for } & \text { the } \\
\text { Management of } & \text { Fish } \\
\text { Habitat 1986 } & & \end{array}$ & $\begin{array}{l}\text { "no net loss of the } \\
\text { productive capacity of fish } \\
\text { habitats" [17] }\end{array}$ & No & $\begin{array}{l}\text { Includes marine fish } \\
\text { habitats. }\end{array}$ & Bank, PRM & Yes & $\begin{array}{l}\text { "The no net loss principle is } \\
\text { fundamental to the habitat } \\
\text { conservation goal. Under this } \\
\text { principle, the Department will } \\
\text { strive to balance unavoidable } \\
\text { habitat losses with habitat } \\
\text { replacement on a project-by- } \\
\text { project basis so that further } \\
\text { reductions to Canada's } \\
\text { fisheries resources due to } \\
\text { habitat loss or damage may } \\
\text { be prevented." [18] }\end{array}$ & $\begin{array}{l}\text { "Only the difference in } \\
\text { productive capacity between } \\
\text { the before and after scenarios } \\
\text { can be considered as } \\
\text { compensatory gains" [19] }\end{array}$ & $\begin{array}{l}\text { "Higher (weighted) ratios are } \\
\text { justified on the basis of } \\
\text { uncertainty of success, variance } \\
\text { in the quality of the fish habitat } \\
\text { being revlace, and recognition } \\
\text { of the lag time required for the } \\
\text { new habitat to become } \\
\text { functional. Lower ratios would } \\
\text { be needed if the compensation } \\
\text { works are completed and } \\
\text { functional before the HADD } \\
\text { occurs." [19] }\end{array}$ & $\begin{array}{l}\text { managed } \\
\text { through } \\
\text { planning } \\
\text { conditions }\end{array}$ & {$[17,19-26]$} \\
\hline Canada & $\begin{array}{l}\text { National } \\
\text { offsetting policy } \\
\text {-application to } \\
\text { restricted to } \\
\text { federal property }\end{array}$ & $\begin{array}{l}\text { Federal Policy on Wetland } \\
\text { Conservation (FPWC) }\end{array}$ & $\begin{array}{l}\text { "no net loss of wetland } \\
\text { functions on all federal } \\
\text { lands and waters" [27] }\end{array}$ & No & $\begin{array}{l}\text { Marine and coastal } \\
\text { area }\end{array}$ & & Yes & $\begin{array}{l}\text { "balance the unavoidable loss } \\
\text { of wetland functions" [28] }\end{array}$ & & & $\begin{array}{l}\text { managed } \\
\text { through } \\
\text { planning } \\
\text { conditions }\end{array}$ & [27-30] \\
\hline \multicolumn{13}{|l|}{ Australia } \\
\hline Australia & $\begin{array}{l}\text { National } \\
\text { offsetting policy }\end{array}$ & 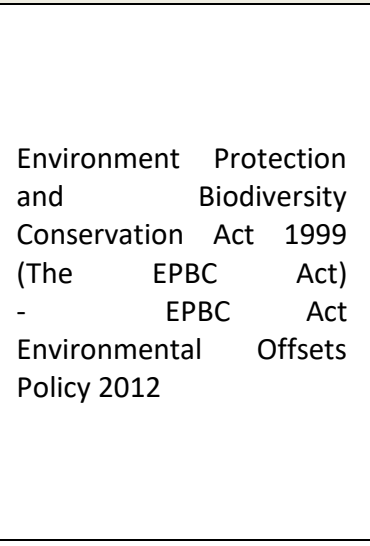 & $\begin{array}{l}\text { "improves or maintains the } \\
\text { viability of the aspect of the } \\
\text { environment that is } \\
\text { protected by national } \\
\text { environment law and } \\
\text { affected by the proposed } \\
\text { action" [31] }\end{array}$ & No & $\begin{array}{l}\text { Applies to marine } \\
\text { and coastal habitats } \\
\text { and species including } \\
\text { Ramsar wetlands, } \\
\text { listed threatened } \\
\text { species and } \\
\text { ecological } \\
\text { communities, } \\
\text { migratory species, } \\
\text { commonwealth } \\
\text { marine areas and, } \\
\text { specifically, the } \\
\text { Great Barrier Reef } \\
\text { marine park. } \\
\end{array}$ & $\begin{array}{l}\text { Bank, ILF, } \\
\text { PRM }\end{array}$ & Yes & $\begin{array}{l}\text { "deliver an overall } \\
\text { conservation outcome that } \\
\text { improves or maintains the } \\
\text { viability of the aspect of the } \\
\text { environment that is protected } \\
\text { by national environment law } \\
\text { and affected by the proposed } \\
\text { action" [31] }\end{array}$ & $\begin{array}{l}\text { "be additional to what is } \\
\text { already required, determined } \\
\text { by law or planning regulations } \\
\text { or agreed to under other } \\
\text { schemes or programs" [31] }\end{array}$ & $\begin{array}{l}\text { "Offsets should compensate for } \\
\text { an impact for the full duration } \\
\text { of the impact. Offsets that } \\
\text { deliver an outcome prior to the } \\
\text { impact commencing are } \\
\text { encouraged, as they minimise } \\
\text { effects on the protected matter } \\
\text { resulting from offset time } \\
\text { delays" [31] }\end{array}$ & $\begin{array}{l}\text { managed } \\
\text { through } \\
\text { planning } \\
\text { conditions }\end{array}$ & [31-35] \\
\hline Australia & $\begin{array}{l}\text { Sub-national } \\
\text { offsetting policy }\end{array}$ & $\begin{array}{l}\text { Queensland: } \\
\text { Environmental Offsets Act } \\
2014 \quad \text { Queensland } \\
-\quad \text { Environmental Offsets } \\
\text { Policy }\end{array}$ & $\begin{array}{l}\text { "provide a conservation } \\
\text { outcome that is equivalent } \\
\text { to the value being lost" [36] }\end{array}$ & No & $\begin{array}{l}\text { Applies to Marine } \\
\text { Fish Habitat, Marine } \\
\text { parks. }\end{array}$ & $\begin{array}{l}\text { Bank, ILF, } \\
\text { PRM }\end{array}$ & Yes & $\begin{array}{l}\text { "Offsets must achieve a } \\
\text { conservation outcome that } \\
\text { achieves an equivalent } \\
\text { environmental outcome." [36] }\end{array}$ & $\begin{array}{l}\text { "Offsets will not replace or } \\
\text { undermine } \\
\text { envirsting } \\
\text { regulatory requirements..." [36] }\end{array}$ & $\begin{array}{l}\text { "Offset provision must } \\
\text { minimise the time-lag between } \\
\text { the impact and delivery of the } \\
\text { offset." [36] } \\
\text { "Where legal security is } \\
\text { required, offsets must te legally } \\
\text { secured for the duration of the } \\
\text { impact on the prescribed } \\
\text { environmental matter." [36] }\end{array}$ & $\begin{array}{l}\text { managed } \\
\text { through } \\
\text { planning } \\
\text { conditions }\end{array}$ & [36-38] \\
\hline
\end{tabular}




\begin{tabular}{|c|c|c|c|c|c|c|c|c|c|c|c|c|}
\hline \multirow[b]{2}{*}{ Country } & \multicolumn{2}{|l|}{ Offset mechanism } & \multirow[b]{2}{*}{ Aim } & \multirow[b]{2}{*}{$\begin{array}{l}\text { Marine } \\
\text { specific }\end{array}$} & \multirow[b]{2}{*}{$\begin{array}{l}\text { Marine relevance if } \\
\text { not specific }\end{array}$} & \multirow[b]{2}{*}{$\begin{array}{l}\text { Instrument } \\
\text { used }\end{array}$} & \multirow[b]{2}{*}{$\begin{array}{l}\text { Mitigation } \\
\text { hierarchy }\end{array}$} & \multirow[b]{2}{*}{ Equivalence } & \multirow[b]{2}{*}{ Additionality } & \multirow[b]{2}{*}{ Continuity } & \multirow[b]{2}{*}{$\begin{array}{l}\text { Compliance } \\
\text { success }\end{array}$} & \multirow[b]{2}{*}{ References } \\
\hline & Type & Detail & & & & & & & & & & \\
\hline Australia & $\begin{array}{l}\text { Investment } \\
\text { strategy } \\
\text { (relating to } \\
\text { national and } \\
\text { sub-national } \\
\text { policy) }\end{array}$ & Reef Trust & $\begin{array}{l}\text { To channel offset finance } \\
\text { (required through EPBC } \\
\text { offsetting requirements) to } \\
\text { strategically address high } \\
\text { priority threats to the } \\
\text { Great Barrier Reef }\end{array}$ & Yes & & Bank, ILF & & $(\text { Yes })^{3}$ & & & Yes & {$[39,40]$} \\
\hline Australia & $\begin{array}{l}\text { Sub-national } \\
\text { offsetting policy }\end{array}$ & $\begin{array}{l}\text { New South Wales: } \\
\text { Fisheries NSW policy and } \\
\text { guidelines for fish habitat } \\
\text { conservation } \\
\text { management }\end{array}$ & $\begin{array}{l}\text { "no net loss of key fish } \\
\text { habitat" [41] }\end{array}$ & No & $\begin{array}{l}\text { Applies to marine } \\
\text { and coastal habitat } \\
\text { including but not } \\
\text { limited to seagrass, } \\
\text { mangroves, } \\
\text { saltmarsh, estuarine } \\
\text { and marine rocky } \\
\text { reefs }\end{array}$ & ILF, PRM & Yes & $\begin{array}{l}\text { "Habitat replacement (as a } \\
\text { compensation measure) will } \\
\text { need to account for indirect as } \\
\text { well as direct impacts of } \\
\text { development to ensure that } \\
\text { there is " "no net loss" of key } \\
\text { fish habitats" [41] }\end{array}$ & & $\begin{array}{l}\text { "Pre-development habitat } \\
\text { compensation (i.e. prior to } \\
\text { disturbance) is recommended } \\
\text { over post-development } \\
\text { compensation i.e.e. after the } \\
\text { habitat is lost)." [41] } \\
\text { "Scientific research and } \\
\text { monitoring programs should be } \\
\text { established to quantify the } \\
\text { impacts of development and } \\
\text { the effectiveness of } \\
\text { environmental mitigation and } \\
\text { compensation molasures. } \\
\text { Management should be } \\
\text { adaptive to incorporate the } \\
\text { findings of these programs." } \\
\text { [41] }\end{array}$ & $\begin{array}{l}\text { managed } \\
\text { through } \\
\text { planning } \\
\text { conditions }\end{array}$ & {$[34,41,42]$} \\
\hline Australia & $\begin{array}{l}\text { Sub-national } \\
\text { offsetting policy }\end{array}$ & Victoria & $\begin{array}{l}\text { "No net loss in the } \\
\text { contribution made by } \\
\text { native vegetation to } \\
\text { Victoria's biodiversity" [43] }\end{array}$ & No & $\begin{array}{l}\text { "plants that are } \\
\text { indigenous to } \\
\text { Victoria, including } \\
\text { trees, shrubs, herbs } \\
\text { and grasses" [43] }\end{array}$ & Bank, PRM & Yes & $\begin{array}{l}\text { "Where native vegetation is } \\
\text { permitted to be removed, } \\
\text { ensure that an offset is } \\
\text { provided in a manner that } \\
\text { makes a contribution to } \\
\text { Victoria's biodiversity that is } \\
\text { equivalent to the contribution } \\
\text { made by the native vegetation } \\
\text { to be removed." [43] }\end{array}$ & $\begin{array}{l}\text { "For the native vegetation on } \\
\text { an offset site to deliver gains in } \\
\text { the contribution to biodiversity } \\
\text { which can be used to offset } \\
\text { removing native vegetation, } \\
\text { management commitments } \\
\text { must be undertaken that } \\
\text { maintain and improve the } \\
\text { condition of native vegetation. } \\
\text { Gain can only be generated by } \\
\text { management commitments } \\
\text { that are in addition to existing } \\
\text { obligations under legislation, } \\
\text { existing agreements or } \\
\text { contracts." [44] }\end{array}$ & $\begin{array}{l}\text { "A compliant offset must be } \\
\text { secured, to the satisfaction of } \\
\text { the responsible or referral } \\
\text { authority, before the native } \\
\text { vegetation is removed." [44] }\end{array}$ & $\begin{array}{l}\text { managed } \\
\text { through } \\
\text { planning } \\
\text { conditions }\end{array}$ & [43-45] \\
\hline
\end{tabular}




\begin{tabular}{|c|c|c|c|c|c|c|c|c|c|c|c|c|}
\hline \multirow[b]{2}{*}{ Country } & \multicolumn{2}{|c|}{ Offset mechanism } & \multirow[b]{2}{*}{ Aim } & \multirow[b]{2}{*}{$\begin{array}{l}\text { Marine } \\
\text { specific }\end{array}$} & \multirow[b]{2}{*}{$\begin{array}{l}\text { Marine relevance if } \\
\text { not specific }\end{array}$} & \multirow[b]{2}{*}{$\begin{array}{l}\text { Instrument } \\
\text { used }\end{array}$} & \multirow[b]{2}{*}{$\begin{array}{l}\text { Mitigation } \\
\text { hierarchy }\end{array}$} & \multirow[b]{2}{*}{ Equivalence } & \multirow[b]{2}{*}{ Additionality } & \multirow[b]{2}{*}{ Continuity } & \multirow[b]{2}{*}{$\begin{array}{l}\text { Compliance } \\
\text { success }\end{array}$} & \multirow[b]{2}{*}{ References } \\
\hline & Type & Detail & & & & & & & & & & \\
\hline Australia & $\begin{array}{l}\text { Sub-national } \\
\text { offsetting policy }\end{array}$ & 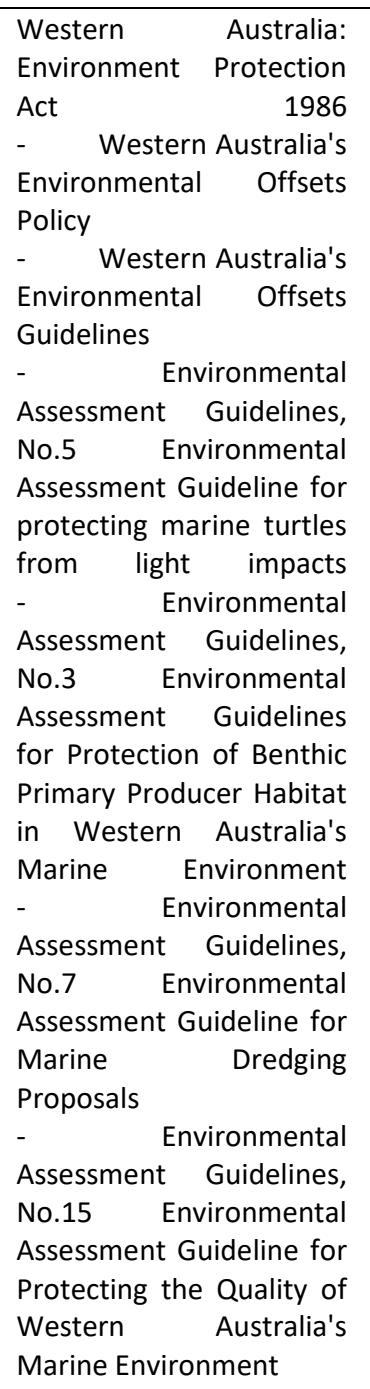 & \begin{tabular}{|lr} 
& "counterbalancer the \\
significant & residual \\
environmental impacts or & risks of a project or activity" \\
[46] &
\end{tabular} & No & $\begin{array}{l}\text { Applies to all WA } \\
\text { lands, inland waters } \\
\text { and marine coastal } \\
\text { waters within three } \\
\text { nautical miles. Native } \\
\text { vegetation includes } \\
\text { marine and aquatic } \\
\text { species. }\end{array}$ & $\begin{array}{l}\text { Bank, ILF, } \\
\text { PRM }\end{array}$ & Yes & $\begin{array}{l}\text { "relevant and proportionate" } \\
\text { and designed to } \\
\text { counterbalance the impact" } \\
{[46]}\end{array}$ & $\begin{array}{l}\text { "Actions undertaken offsite } \\
\text { which are required by other } \\
\text { legislation generally cannot be } \\
\text { considered an offset." [46] }\end{array}$ & $\begin{array}{l}\text { "However, while rehabilitation } \\
\text { is an important component of } \\
\text { the mitigation hierarchy, not all } \\
\text { environmental values can be } \\
\text { effectively } \\
\text { rehabilitated. Some values or } \\
\text { ecosystem functions may be } \\
\text { permanently lost, and it may be } \\
\text { necessary to consider the time } \\
\text { lag before values are re- } \\
\text { established to the maximum } \\
\text { extent possible." [46] } \\
\text { "Where an impact creates a } \\
\text { temporary loss of value, the } \\
\text { length of the offset should be } \\
\text { matched to counterbalance this } \\
\text { temporary impact. If an impact } \\
\text { is permanent, offsets must } \\
\text { ensure a long lasting } \\
\text { environmental benefit and be } \\
\text { capable of being maintained } \\
\text { into the future (including after } \\
\text { the project has been } \\
\text { completed)." [46] }\end{array}$ & $\begin{array}{l}\text { managed } \\
\text { through } \\
\text { planning } \\
\text { conditions }\end{array}$ & {$[46-52]$} \\
\hline Australia & $\begin{array}{l}\text { Sub-national } \\
\text { offsetting policy }\end{array}$ & 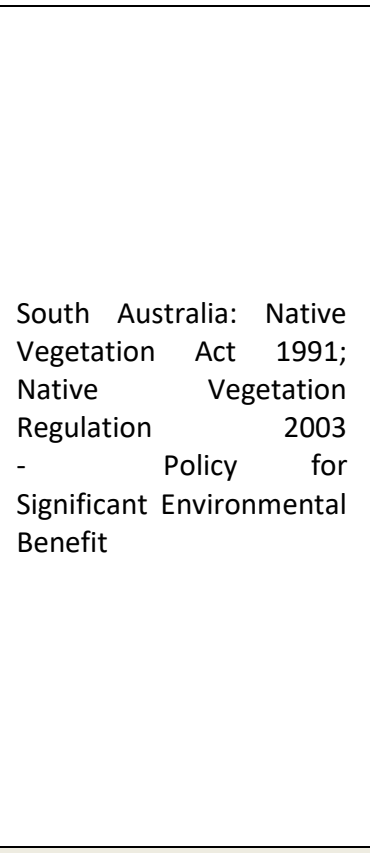 & $\begin{array}{l}\text { "significant environmental } \\
\text { benefit (SEB), which is over } \\
\text { and above the impact of } \\
\text { the clearance" [53] }\end{array}$ & No & $\begin{array}{l}\text { "native vegetation } \\
\text { means a plant or } \\
\text { plants of a species } \\
\text { indigenous to South } \\
\text { Australia including a } \\
\text { plant or plants } \\
\text { growing in or under } \\
\text { waters of the sea..." } \\
{[54]}\end{array}$ & $\begin{array}{l}\text { Bank, ILF, } \\
\text { PRM }\end{array}$ & Yes & $\begin{array}{l}\text { "In order to achieve a net gain, } \\
\text { a method for calculating the } \\
\text { loss at the development site } \\
\text { and the potential gain at the } \\
\text { proposed SEB area will be } \\
\text { used. The offset design and } \\
\text { implementation includes } \\
\text { provisions for addressing } \\
\text { sources of uncertainty and risk } \\
\text { of failure in delivering the } \\
\text { SEB." [53] }\end{array}$ & $\begin{array}{l}\text { "...biodiversity offsets need to } \\
\text { be new, or additional, to what is } \\
\text { required by duty of care or any } \\
\text { other environmental and } \\
\text { planning legislation at any level } \\
\text { of government... Offsets must } \\
\text { be additional to what has been } \\
\text { paid for by other programs or } \\
\text { schemes, such as stewardship } \\
\text { programs, carbon } \\
\text { sequestration projects or other } \\
\text { environmental programs where } \\
\text { funds are allocated to land } \\
\text { owners to manage biodiversity } \\
\text { on their properties.... Offsets } \\
\text { must provide a gain that is } \\
\text { additional to what would likely } \\
\text { have occurred in the absence of } \\
\text { the offset area beifg } \\
\text { established (considering the } \\
\text { likely trajectory of any change } \\
\text { in vegetation condition)." [53] }\end{array}$ & $\begin{array}{l}\text { "Offsets need to secure } \\
\text { outcomes for at least as long as } \\
\text { the project's impact. The } \\
\text { impacts of most projects are } \\
\text { permanent and therefore } \\
\text { offsets generally need to be } \\
\text { secured in perpetuity." [53] } \\
\text { "The SEB area should be } \\
\text { established and management } \\
\text { initiated at the time of, or prior } \\
\text { to, the approved clearance } \\
\text { being undertaken." [53] }\end{array}$ & $\begin{array}{l}\text { managed } \\
\text { through } \\
\text { planning } \\
\text { conditions }\end{array}$ & [53-55] \\
\hline Europe & & & & & & & & & & & & \\
\hline
\end{tabular}




\begin{tabular}{|c|c|c|c|c|c|c|c|c|c|c|c|c|}
\hline \multirow[b]{2}{*}{ Country } & \multicolumn{2}{|l|}{ Offset mechanism } & \multirow[b]{2}{*}{ Aim } & \multirow[b]{2}{*}{\begin{tabular}{|l} 
Marine \\
specific
\end{tabular}} & \multirow[b]{2}{*}{$\begin{array}{l}\text { Marine relevance if } \\
\text { not specific }\end{array}$} & \multirow[b]{2}{*}{$\begin{array}{l}\text { Instrument } \\
\text { used }\end{array}$} & \multirow[b]{2}{*}{$\begin{array}{l}\text { Mitigation } \\
\text { hierarchy }\end{array}$} & \multirow[b]{2}{*}{ Equivalence } & \multirow[b]{2}{*}{ Additionality } & \multirow[b]{2}{*}{ Continuity } & \multirow[b]{2}{*}{$\begin{array}{l}\text { Compliance } \\
\text { success }\end{array}$} & \multirow[b]{2}{*}{ References } \\
\hline & Type & Detail & & & & & & & & & & \\
\hline $\begin{array}{l}\text { European } \\
\text { Union }\end{array}$ & $\begin{array}{l}\text { Emergent } \\
\text { (supra-) national } \\
\text { offsetting policy } \\
\text { [on hold] }]^{4}\end{array}$ & $\begin{array}{l}\text { Biodiversity strategy to } \\
\text { "halt biodiversity and } \\
\text { ecosystem service loss by } \\
2020 \text { " }\end{array}$ & $\begin{array}{l}\text { To address biodiversity } \\
\text { losses outside of protected } \\
\text { areas. }\end{array}$ & No & $\begin{array}{l}\text { Includes marine } \\
\text { environments }\end{array}$ & & $n / a$ & $n / a$ & $n / a$ & $n / a$ & $n / a$ & [56-58] \\
\hline $\begin{array}{l}\text { European } \\
\text { Union }\end{array}$ & $\begin{array}{l}\text { Supra-national } \\
\text { offsetting policy } \\
-\quad \text { application } \\
\text { restricted to } \\
\text { designated sites }\end{array}$ & \begin{tabular}{|lll} 
European & Union & (EU) \\
Habitats & and & Birds \\
Directives & &
\end{tabular} & $\begin{array}{l}\text { "overall coherence lof } \\
\text { network]" [59] }\end{array}$ & No & $\begin{array}{l}\text { Includes marine birds } \\
\text { and habitats }\end{array}$ & ILF, PRM & Yes & $\begin{array}{l}\text { "aim to offset the negative } \\
\text { impact of a project and to } \\
\text { provide compensation } \\
\text { corresponding precisely to the } \\
\text { negative effects on the species } \\
\text { or habitat concerned" [59] } \\
\text { "ecological coherence lof } \\
\text { network]" [59] }\end{array}$ & $\begin{array}{l}\text { "Compensatory measures } \\
\text { should be additional to the } \\
\text { actions that are normal practice } \\
\text { under the Habitats and Birds } \\
\text { Directives or obligations laid } \\
\text { down in EC law." [59] }\end{array}$ & & \begin{tabular}{|l} 
managed \\
through \\
planning \\
conditions
\end{tabular} & [59-63] \\
\hline France & $\begin{array}{l}\text { National } \\
\text { offsetting policy }\end{array}$ & \begin{tabular}{|lr}
$\begin{array}{l}\text { Doctrine } \\
\text { guidelines }\end{array}$ & and \\
outlining implementation \\
of mitigation hierarchy
\end{tabular} & $\begin{array}{l}\text { no net loss as outlined in } \\
\text { other public policies. }\end{array}$ & No & $\begin{array}{l}\text { Includes marine } \\
\text { habitats and species }\end{array}$ & Bank, PRM & Yes & $\begin{array}{l}\text { "Offset measures must restore } \\
\text { environmental quality of the } \\
\text { impacted biodiversity to a } \\
\text { level at least equivalent to its } \\
\text { initial level and if possible a } \\
\text { better state..." [64,65] }\end{array}$ & $\begin{array}{l}\text { "Offset measures must be } \\
\text { additional to existing or } \\
\text { planned public policy targets } \\
\text { for biodiversity and ecosystems. } \\
\text { They can complement these } \\
\text { policies but not substitute } \\
\text { them." }[64,65]\end{array}$ & $\begin{array}{l}\text { "Offset measures must be } \\
\text { timely and no irreversible } \\
\text { damage must be done before } \\
\text { offset measures are in place. } \\
\text { Exceptions can be made when it } \\
\text { is demonstrated that they do } \\
\text { not compromise the efficacy of } \\
\text { the offset measures." [64,65] } \\
\text { "The outcome of offsets } \\
\text { measures must be of sufficient } \\
\text { duration, and proportional to } \\
\text { the duration of impacts." } \\
{[64,65]}\end{array}$ & \begin{tabular}{|l} 
managed \\
through \\
planning \\
conditions
\end{tabular} & {$[57,64-68]$} \\
\hline Germany & $\begin{array}{l}\text { National } \\
\text { offsetting policy }\end{array}$ & \begin{tabular}{|lr} 
Federal & Nature \\
Conservation Act & (FNCA) \\
and Federal Building Code
\end{tabular} & $\begin{array}{l}\text { "Intervening parties shall } \\
\text { primarily avoid any } \\
\text { significant adverse effects } \\
\text { on nature and landscape. } \\
\text { Unavoidable significant } \\
\text { adverse effects are to be } \\
\text { offset via compensation } \\
\text { measures } \\
\text { (Ausgleichsmabnahmen) or } \\
\text { substitution measures } \\
\text { (Ersatzmannahmen) or } \\
\text { where such offset is not } \\
\text { possible, via money } \\
\text { substitution"[69] mat }\end{array}$ & No & $\begin{array}{l}\text { Applicable to } \\
\text { "impacts on soil, } \\
\text { water, air and } \\
\text { climatefunctions and } \\
\text { associated } \\
\text { biodivesity and } \\
\text { landscape values" } \\
{[57]}\end{array}$ & $\begin{array}{l}\text { Bank, ILF, } \\
\text { PRM }\end{array}$ & Yes & $\begin{array}{l}\text { "The intervening party is } \\
\text { obligated to compensate for } \\
\text { any unavoidable adverse } \\
\text { effects by means of nature } \\
\text { conservation and landscape } \\
\text { management measures } \\
\text { (compensation measures) or } \\
\text { to substitute them in some } \\
\text { other way (substitution } \\
\text { measures). An adverse effect } \\
\text { shall be considered to have } \\
\text { been compensated as soon as } \\
\text { the impaired functions of the } \\
\text { natural balance have been } \\
\text { restored in an equivalent way } \\
\text { and landscape appearance } \\
\text { has been restored or re- } \\
\text { designed in a manner } \\
\text { consistent with the landscape. } \\
\text { An adverse effect shall be } \\
\text { considered to have been } \\
\text { substituted as soon as the } \\
\text { impaired functions of the } \\
\text { natural balance, in the } \\
\text { relevant natural area, have } \\
\text { been restored to an equivalent } \\
\text { value and landscape } \\
\text { appearance has been re- } \\
\text { designed in a manner } \\
\text { consistent with the } \\
\text { landscape."[69] }\end{array}$ & $\begin{array}{l}\text { "Measures that already result } \\
\text { from other legal requirements } \\
\text { or which are public funded } \\
\text { cannot be considered as } \\
\text { compensation measures." [57] }\end{array}$ & $\begin{array}{l}\text { "Compensation and } \\
\text { substitution measures shall be } \\
\text { maintained throughout the } \\
\text { relevant required period and } \\
\text { shall be legally protected. The } \\
\text { relevant maintenance period } \\
\text { shall be set forth by the } \\
\text { competent authority in the } \\
\text { relevant official approval } \\
\text { notice. The intervening party, } \\
\text { or his legal successor, shall be } \\
\text { responsible for carrying out, } \\
\text { maintaining and securing } \\
\text { compensation and substitution } \\
\text { measures" [69] }\end{array}$ & \begin{tabular}{|l} 
managed \\
through \\
planning \\
conditions
\end{tabular} & {$[12,57,69]$} \\
\hline
\end{tabular}




\begin{tabular}{|c|c|c|c|c|c|c|c|c|c|c|c|c|}
\hline \multirow[b]{2}{*}{ Country } & \multicolumn{2}{|l|}{\begin{tabular}{|l|} 
Offset mechanism \\
\end{tabular}} & \multirow[b]{2}{*}{ Aim } & \multirow[b]{2}{*}{$\begin{array}{l}\text { Marine } \\
\text { specific }\end{array}$} & \multirow[b]{2}{*}{$\begin{array}{l}\text { Marine relevance if } \\
\text { not specific }\end{array}$} & \multirow[b]{2}{*}{$\begin{array}{l}\text { Instrument } \\
\text { used }\end{array}$} & \multirow[b]{2}{*}{$\begin{array}{l}\text { Mitigation } \\
\text { hierarchy }\end{array}$} & \multirow[b]{2}{*}{ Equivalence } & \multirow[b]{2}{*}{ Additionality } & \multirow[b]{2}{*}{ Continuity } & \multirow[b]{2}{*}{$\begin{array}{l}\text { Compliance } \\
\text { success }\end{array}$} & \multirow[b]{2}{*}{ References } \\
\hline & Type & Detail & & & & & & & & & & \\
\hline $\begin{array}{l}\text { The } \\
\text { Netherlands }\end{array}$ & $\begin{array}{l}\text { National policy } \\
\text { requiring partial } \\
\text { application of } \\
\text { offseting } \\
\text { principles }\end{array}$ & $\begin{array}{l}\text { Dutch National Nature } \\
\text { Network established } \\
\text { under the Infrastructure } \\
\text { and spatial planning } \\
\text { policy. }\end{array}$ & $\begin{array}{l}\text { long term sustainable } \\
\text { development }\end{array}$ & No & $\begin{array}{l}\text { Applies to protected } \\
\text { areas that include } \\
\text { those in marine } \\
\text { environments. }\end{array}$ & & Yes & $\begin{array}{l}\text { "Compensation for the loss of } \\
\text { protected areas must be } \\
\text { compensated for by } \\
\text { establishing a new area of } \\
\text { land to perform that function } \\
\text { (like-for-like compensation)." } \\
\text { [57] }\end{array}$ & & $\begin{array}{l}\text { "The National Nature Network } \\
\text { requires that a correction factor } \\
\text { be applied to the areas that are } \\
\text { developed within the Network } \\
\text { in order to compensate for the } \\
\text { qualitative loss of nature values } \\
\text { during the time that the new } \\
\text { area needs for development to } \\
\text { a mature stage" [56,57,70] }\end{array}$ & $\begin{array}{l}\text { managed } \\
\text { through } \\
\text { planning } \\
\text { conditions }\end{array}$ & {$[56,57,70]$} \\
\hline $\begin{array}{l}\text { United } \\
\text { Kingdom }\end{array}$ & \begin{tabular}{|l|} 
Emergent \\
national \\
offsetting policy \\
(on hold)
\end{tabular} & $\begin{array}{l}\text { Offsetting pilot studies } \\
\text { not progressed }\end{array}$ & To explore use of offsets & No & $\begin{array}{l}\text { Included coastal } \\
\text { study sites. Subtidal } \\
\text { areas were excluded } \\
\text { from scope. } \\
\end{array}$ & & & & & & & [71-73] \\
\hline $\begin{array}{l}\text { United } \\
\text { Kingdom }\end{array}$ & \begin{tabular}{|l} 
Biodiversity \\
markets
\end{tabular} & $\begin{array}{l}\text { Private investment in } \\
\text { marine offset feasibility } \\
\text { (The Crown Estate) }\end{array}$ & $\begin{array}{l}\text { Alignment of stewardship } \\
\text { and revenue raising } \\
\text { streams of organisation }\end{array}$ & Yes & & & & & & & & [73] \\
\hline $\begin{array}{l}\text { United } \\
\text { Kingdom }\end{array}$ & $\begin{array}{l}\text { Biodiversity } \\
\text { offset research } \\
\text { and } \\
\text { development } \\
\text { (R\&D) }\end{array}$ & $\begin{array}{l}\text { Regulator led research } \\
\text { and development project } \\
\text { into "The location, } \\
\text { condition and features of } \\
\text { significant sites" }\end{array}$ & $\begin{array}{l}\text { To improve knowledge } \\
\text { around potential sites for } \\
\text { easy habitat } \\
\text { creation/restoration to } \\
\text { assist in the marine } \\
\text { development applications } \\
\text { with compensatory } \\
\text { requirements. }\end{array}$ & Yes & & & & & & & & [74] \\
\hline \multicolumn{13}{|l|}{ Africa } \\
\hline South Africa & \begin{tabular}{|l|} 
Emergent \\
national \\
offsetting policy
\end{tabular} & $\begin{array}{l}\text { South African centralised } \\
\text { biodiversity offsetting } \\
\text { policy }\end{array}$ & & No & $\begin{array}{ll}\text { Supported } & \text { by } \\
\text { requirements } & \text { of } \\
\text { NEMA. } & \end{array}$ & & & & & & & [75-79] \\
\hline South Africa & $\begin{array}{l}\text { National policy } \\
\text { supporting } \\
\text { development of } \\
\text { offsetting- } \\
\text { specific policy }\end{array}$ & $\begin{array}{l}\text { National Environment } \\
\text { Management Act (NEMA) } \\
\text { (Act 107 or 1998) }\end{array}$ & $\begin{array}{l}\text { "disturbance of ecosystems } \\
\text { and loss of biological } \\
\text { diversity should be avoided } \\
\text { or, where it cannot be } \\
\text { altogether avoided, } \\
\text { minimised and remedied" } \\
\text { and "environment is held in } \\
\text { public trust... protected as } \\
\text { the people's common } \\
\text { heritage" [80] }\end{array}$ & No & $\begin{array}{l}\text { Extends to land } \\
\text { below the high water } \\
\text { mark and further } \\
\text { provisions for the } \\
\text { protection of marine } \\
\text { receptors are } \\
\text { provided through the } \\
\text { National } \\
\text { Environmental } \\
\text { Management: } \\
\text { Integrated Coastal } \\
\text { Management Act }\end{array}$ & & Yes & & & & $\begin{array}{l}\text { managed } \\
\text { through } \\
\text { planning } \\
\text { conditions }\end{array}$ & {$[76,81-85]$} \\
\hline South Africa & $\begin{array}{l}\text { Sub-national } \\
\text { offsetting policy }\end{array}$ & $\begin{array}{l}\text { Western Cape - provincial } \\
\text { guideline on biodiversity } \\
\text { offsets }\end{array}$ & $\begin{array}{l}\text { Adherence to NEMA's } \\
\text { principles }\end{array}$ & No & $\begin{array}{l}\text { "... deals primarily } \\
\text { with terrestrial } \\
\text { ecosystems and } \\
\text { wetlands (a type of } \\
\text { freshwater } \\
\text { ecosystem)." [78] }\end{array}$ & PRM, ILF & Yes & $\begin{array}{l}\text { "Offsets must ensure } \\
\text { sustainable development } \\
\text { through compensating for } \\
\text { biodiversity impact by } \\
\text { contributing to biodiversity } \\
\text { conservation, and should } \\
\text { conserve biodiversity of at } \\
\text { least as high significance as } \\
\text { that impacted by the } \\
\text { proposed development." [78] }\end{array}$ & $\begin{array}{l}\text { "Offsets should not comprise } \\
\text { actions or activities already } \\
\text { required by law." [78] }\end{array}$ & $\begin{array}{l}\text { "Offsets in the most } \\
\text { appropriate form must be } \\
\text { secured before development } \\
\text { commences, to give assurance } \\
\text { of effectiveness." [78] } \\
\text { "Offsets must provide long } \\
\text { term security for tenure." [78] } \\
\text { "Offset must provide long term } \\
\text { security for management" [78] }\end{array}$ & $\begin{array}{l}\text { managed } \\
\text { through } \\
\text { planning } \\
\text { conditions }\end{array}$ & {$[78,86]$} \\
\hline
\end{tabular}




\begin{tabular}{|c|c|c|c|c|c|c|c|c|c|c|c|c|}
\hline \multirow[b]{2}{*}{ Country } & \multicolumn{2}{|l|}{ Offset mechanism } & \multirow[b]{2}{*}{ Aim } & \multirow[b]{2}{*}{$\begin{array}{l}\text { Marine } \\
\text { specific }\end{array}$} & \multirow[b]{2}{*}{$\begin{array}{l}\text { Marine relevance if } \\
\text { not specific }\end{array}$} & \multirow[b]{2}{*}{$\begin{array}{l}\text { Instrument } \\
\text { used }\end{array}$} & \multirow[b]{2}{*}{$\begin{array}{l}\text { Mitigation } \\
\text { hierarchy }\end{array}$} & \multirow[b]{2}{*}{ Equivalence } & \multirow[b]{2}{*}{ Additionality } & \multirow[b]{2}{*}{ Continuity } & \multirow[b]{2}{*}{$\begin{array}{l}\text { Compliance } \\
\text { success }\end{array}$} & \multirow[b]{2}{*}{ References } \\
\hline & Type & Detail & & & & & & & & & & \\
\hline South Africa & $\begin{array}{l}\text { Sub-national } \\
\text { offsetting policy }\end{array}$ & $\begin{array}{l}\text { KwaZulu-Natal - offsetting } \\
\text { scheme and guideline }\end{array}$ & $\begin{array}{l}\text { Adherence to NEMA's } \\
\text { principles }\end{array}$ & No & $\begin{array}{l}\text { Supported by KZN } \\
\text { biodiversity plans to } \\
\text { identify areas of } \\
\text { importance - } \\
\text { includes estuarine } \\
\text { environments and } \\
\text { links to offshore } \\
\text { counterparts } \\
\text { highlighted in } \\
\text { Coastal and Marine } \\
\text { Biodiversity Plan. }\end{array}$ & $\begin{array}{l}\text { Bank, ILF, } \\
\text { PRM }\end{array}$ & Yes & $\begin{array}{l}\text { "offsets must address all } \\
\text { significant residual impacts on } \\
\text { biodiversity; direct, indirect } \\
\text { and cumulative" [77] } \\
\text { "offsets must explicitly target } \\
\text { the pattern, process and/or } \\
\text { ecosystem services residually } \\
\text { impacted by the proposed } \\
\text { development..." [77] } \\
\text { "offsets must consider and } \\
\text { compensate for averse } \\
\text { impacts on biodiversity and } \\
\text { ecosystem services with } \\
\text { intrinsic, use and non-use } \\
\text { values to affected } \\
\text { communities in particular, and } \\
\text { society as a whole, giving } \\
\text { special attention to vulnerable } \\
\text { or disadvantaged parties." } \\
{[777]}\end{array}$ & $\begin{array}{l}\text { "offsets must be 'new' } \\
\text { conservation activities, over } \\
\text { and above outcomes that } \\
\text { would have occurred without } \\
\text { the offset; e.g. existing or } \\
\text { planned conservation areas } \\
\text { cannot be used to ffset a new } \\
\text { activity. Also, offsets should not } \\
\text { comprise actions or activities } \\
\text { already required by law." [77] }\end{array}$ & $\begin{array}{l}\text { "offsets must last for the } \\
\text { duration of project impacts5 or } \\
\text { in perpetuity. } \\
\text { They should be monitored and } \\
\text { managed adaptively to sustain } \\
\text { desired ans." conservation } \\
\text { outcomes." [77] } \\
\text { "offsets in the most appropriate } \\
\text { form must preferably be } \\
\text { secured before development } \\
\text { commences." [77] }\end{array}$ & $\begin{array}{l}\text { Managed } \\
\text { through } \\
\text { planning } \\
\text { conditions }\end{array}$ & {$[77,85]$} \\
\hline Liberia & \begin{tabular}{|l|} 
Sectoral \\
offsetting policy
\end{tabular} & Draft mining act & \begin{tabular}{|l|} 
References \\
performance standard 6 \\
aim of no net loss
\end{tabular} & No & $\begin{array}{l}\text { Contribution to } \\
\text { protected area } \\
\text { commitments which } \\
\text { extend into the } \\
\text { marine and coastal } \\
\text { environment. }\end{array}$ & & Yes & $\begin{array}{l}\text { "In areas of natural habitat, } \\
\text { mitigation measures will be } \\
\text { designed to achieve no net } \\
\text { loss of biodiversity where } \\
\text { feasible" [87,88] }\end{array}$ & & & $\begin{array}{l}\text { managed } \\
\text { through } \\
\text { planning } \\
\text { conditions }\end{array}$ & [87-89] \\
\hline Liberia & \begin{tabular}{|l|} 
Sectoral \\
offsetting policy
\end{tabular} & $\begin{array}{l}\text { Mineral Development } \\
\text { Agreements }\end{array}$ & \begin{tabular}{|l} 
Integrating \\
performance standard 6 \\
aim of no net loss
\end{tabular} & No & $\begin{array}{l}\text { Contribution to } \\
\text { protected area } \\
\text { commitments which } \\
\text { extend into the } \\
\text { marine and coastal } \\
\text { environment. }\end{array}$ & & Yes & $\begin{array}{l}\text { "In areas of natural habitat, } \\
\text { mitigation measures will be } \\
\text { designed to achieve no net } \\
\text { loss of biodiversity where } \\
\text { feasible" }[87,88]\end{array}$ & & & $\begin{array}{l}\text { managed } \\
\text { through } \\
\text { planning } \\
\text { conditions }\end{array}$ & [87-89] \\
\hline Liberia & $\begin{array}{l}\text { Private } \\
\text { standards* } \\
\text { (requirements of } \\
\text { the IFC and other } \\
\text { development } \\
\text { banks only) }\end{array}$ & $\begin{array}{l}\text { Offsets framework for } \\
\text { mining sector }\end{array}$ & $\begin{array}{l}\text { Led by World Bank Group } \\
\text { to contribute to protected } \\
\text { area commitments. }\end{array}$ & No & $\begin{array}{l}\text { Contribution to } \\
\text { protected area } \\
\text { commitments which } \\
\text { extend into the } \\
\text { marine and coastal } \\
\text { environment. }\end{array}$ & & Yes & $\begin{array}{l}\text { "In areas of natural habitat, } \\
\text { mitigation measures will be } \\
\text { designed to achieve no net } \\
\text { loss of biodiversity where } \\
\text { feasible" }[87,88]\end{array}$ & & & $\begin{array}{l}\text { managed } \\
\text { through } \\
\text { planning } \\
\text { conditions }\end{array}$ & [87-89] \\
\hline Mozambique & Sectoral policy & $\begin{array}{l}\text { Article } 23 \text { of the } \\
\text { Petroleum Laws }\end{array}$ & 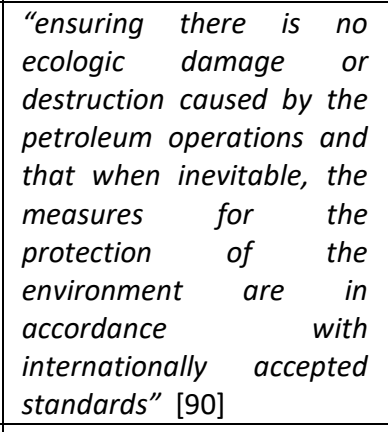 & No & $\begin{array}{l}\text { Relates to oil and gas } \\
\text { operators with } \\
\text { offshore assets. }\end{array}$ & & Yes & $\begin{array}{l}\text { Implies application of IFC } \\
\text { Performance Standard } 6 \text { "'In } \\
\text { areas of natural habitat, } \\
\text { mitigation measures will be } \\
\text { designed to achieve no net } \\
\text { loss of biodiversity where } \\
\text { feasible" [88] }\end{array}$ & & & & {$[88,90-92]$} \\
\hline Mozambique & $\begin{array}{l}\text { Conservation } \\
\text { fund }\end{array}$ & BIOFUND & $\begin{array}{l}\text { To support fiscal } \\
\text { instruments such as } \\
\text { biodiversity offsets to fund } \\
\text { conservation initiatives }\end{array}$ & No & $\begin{array}{l}\text { Protection of } \\
\text { Mozambique's } \\
\text { marine environment } \\
\text { is a well-recognised } \\
\text { conservation } \\
\text { priority. }\end{array}$ & ILF & & & & $\begin{array}{l}\text { Third party action to ensure } \\
\text { delivery by proponent. }\end{array}$ & $\begin{array}{l}\text { Third party } \\
\text { action to } \\
\text { ensure } \\
\text { delivery by } \\
\text { proponent. }\end{array}$ & [93-96] \\
\hline
\end{tabular}




\begin{tabular}{|c|c|c|c|c|c|c|c|c|c|c|c|c|}
\hline \multirow[b]{2}{*}{ Country } & \multicolumn{2}{|l|}{ Offset mechanism } & \multirow[b]{2}{*}{ Aim } & \multirow[b]{2}{*}{$\begin{array}{l}\text { Marine } \\
\text { specific }\end{array}$} & \multirow[b]{2}{*}{$\begin{array}{l}\text { Marine relevance if } \\
\text { not specific }\end{array}$} & \multirow[b]{2}{*}{$\begin{array}{l}\text { Instrument } \\
\text { used }\end{array}$} & \multirow[b]{2}{*}{$\begin{array}{l}\text { Mitigation } \\
\text { hierarchy }\end{array}$} & \multirow[b]{2}{*}{ Equivalence } & \multirow[b]{2}{*}{ Additionality } & \multirow[b]{2}{*}{ Continuity } & \multirow[b]{2}{*}{$\begin{array}{l}\text { Compliance } \\
\text { success }\end{array}$} & \multirow[b]{2}{*}{ References } \\
\hline & Type & Detail & & & & & & & & & & \\
\hline Gabon & $\begin{array}{l}\text { Corporate } \\
\text { standards }\end{array}$ & Private standards - Tullow & $\begin{array}{l}\text { Partnership with Wildlife } \\
\text { Conservation Society to } \\
\text { improve EIA processes and } \\
\text { the application of the } \\
\text { mitigation hierarchy in } \\
\text { offshore environments. }\end{array}$ & Yes & & & Yes & & & & & [97-99] \\
\hline \multicolumn{13}{|l|}{ Asia } \\
\hline China & $\begin{array}{l}\text { Resource access } \\
\text { fee }\end{array}$ & $\begin{array}{l}\text { Marine Ecological } \\
\text { Damage Compensation } \\
\text { (MEDC) requirements. }\end{array}$ & $\begin{array}{l}\text { to achieve sustainable } \\
\text { development and "to make } \\
\text { developers of ocean space } \\
\text { pay the full costs } \\
\text { associated with their } \\
\text { activities, including } \\
\text { damages to the marine } \\
\text { ecosystems" [100] }\end{array}$ & Yes & & ILF & & $\begin{array}{l}\text { "to make developers of ocean } \\
\text { space pay the full costs } \\
\text { associated with their } \\
\text { activities, including damages } \\
\text { to the marine ecosystems" } \\
{[100]}\end{array}$ & & & $\begin{array}{l}\text { Managed } \\
\text { through } \\
\text { access fee }\end{array}$ & [100-102] \\
\hline Korea & $\begin{array}{l}\text { National policy } \\
\text { requiring partial } \\
\text { application of } \\
\text { offsetting } \\
\text { principles }\end{array}$ & $\begin{array}{l}\text { Act on the Conservation } \\
\text { and the Use of } \\
\text { Biodiversity }\end{array}$ & $\begin{array}{l}\text { Fixed charge relating to } \\
\text { construction costs to be } \\
\text { held as a bond against } \\
\text { compensation. }\end{array}$ & No & $\begin{array}{l}\text { Applicable to marine } \\
\text { development, } \\
\text { discussions have } \\
\text { been held as to how } \\
\text { a no net loss policy } \\
\text { might be applied to } \\
\text { manage marine } \\
\text { impacts. }\end{array}$ & & & & & & $\begin{array}{l}\text { Return of } \\
\text { bond } \\
\text { dependent } \\
\text { on success. }\end{array}$ & [103-109] \\
\hline Yemen & $\begin{array}{l}\text { Corporate } \\
\text { standards }\end{array}$ & $\begin{array}{l}\text { Yemen LNG Company } \\
\text { Biodiversity Action Plan }\end{array}$ & $\begin{array}{l}\text { "Company goal to achieve } \\
\text { internationally recognized } \\
\text { environmental } \\
\text { performance in biodiversity } \\
\text { conservation during all } \\
\text { phases of design, } \\
\text { construction, operation } \\
\text { and decommissioning of } \\
\text { the plant." [110] }\end{array}$ & & & PRM & Yes & $\begin{array}{l}\text { "Providing compensation } \\
\text { commensurate with loss, } \\
\text { where negative impact cannot } \\
\text { be fully redressed, and to do } \\
\text { so in a legal, transparent and } \\
\text { ethical manner." [110] } \\
\\
\text { In alignment with IFC } \\
\text { performance standard } 6\end{array}$ & & & & [110] \\
\hline \multicolumn{13}{|c|}{ Central and South America } \\
\hline Argentina & $\begin{array}{l}\text { National policy } \\
\text { requiring partial } \\
\text { application of } \\
\text { offsetting } \\
\text { principles }\end{array}$ & $\begin{array}{l}\text { National Environmental } \\
\text { Law (Ley General del } \\
\text { Ambiente) }\end{array}$ & $\begin{array}{l}\text { "sustainable and adequate } \\
\text { management of the } \\
\text { environment, } \\
\text { preservation the } \\
\text { protection of biological } \\
\text { diversity and the } \\
\text { implementation of } \\
\text { sustainable development" } \\
\text { [111] }\end{array}$ & No & 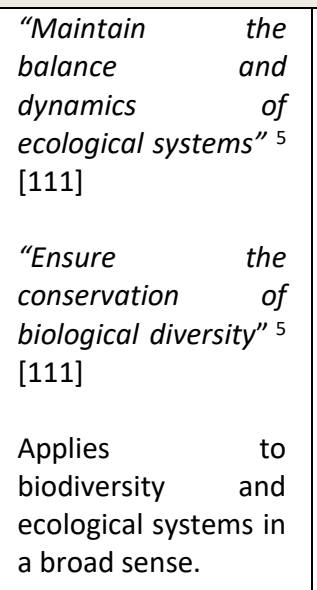 & ILF, PRM & Yes & $\begin{array}{l}\text { "...those that cause the } \\
\text { environmental damage will be } \\
\text { objectively responsible for its } \\
\text { restoration to the state prior } \\
\text { to its production"s [111] }\end{array}$ & & & $\begin{array}{l}\text { Managed } \\
\text { through } \\
\text { conditions }\end{array}$ & [111] \\
\hline
\end{tabular}




\begin{tabular}{|c|c|c|c|c|c|c|c|c|c|c|c|c|}
\hline \multirow[b]{2}{*}{ Country } & \multicolumn{2}{|l|}{ Offset mechanism } & \multirow[b]{2}{*}{ Aim } & \multirow[b]{2}{*}{$\begin{array}{l}\text { Marine } \\
\text { specific }\end{array}$} & \multirow[b]{2}{*}{$\begin{array}{l}\text { Marine relevance if } \\
\text { not specific }\end{array}$} & \multirow[b]{2}{*}{$\begin{array}{l}\text { Instrument } \\
\text { used }\end{array}$} & \multirow[b]{2}{*}{$\begin{array}{l}\text { Mitigation } \\
\text { hierarchy }\end{array}$} & \multirow[b]{2}{*}{ Equivalence } & \multirow[b]{2}{*}{ Additionality } & \multirow[b]{2}{*}{ Continuity } & \multirow[b]{2}{*}{$\begin{array}{l}\text { Compliance } \\
\text { success }\end{array}$} & \multirow[b]{2}{*}{ References } \\
\hline & Type & Detail & & & & & & & & & & \\
\hline Belize & \begin{tabular}{|l} 
Emergent \\
national \\
offsetting policy
\end{tabular} & $\begin{array}{l}\text { Voluntary marine and } \\
\text { coastal offsets framework }\end{array}$ & $\begin{array}{l}\text { To address growing threats } \\
\text { to marine biodiversity in } \\
\text { Belize. }\end{array}$ & Yes & $\begin{array}{l}\text { Also includes coastal } \\
\text { zone in recognition } \\
\text { of influence on } \\
\text { coastal waters. }\end{array}$ & & Yes & $\begin{array}{l}\text { "Impacts on a particular } \\
\text { biotope or habitat should } \\
\text { generally be offset through } \\
\text { "like-for-like' or 'ecological } \\
\text { equivalent" [112] }\end{array}$ & $\begin{array}{l}\text { "Ensure that gains are } \\
\text { additional and can be linked } \\
\text { directly to offset activity" [112] }\end{array}$ & \begin{tabular}{|l|} 
"It is preferable that \\
proponents deliver the required \\
boodiversity offsets before the \\
development or project \\
commences to ensure that \\
there is no time lag between \\
the loss of biodiversity due to \\
the project and the gain in \\
biodiversity delivered through \\
offsets" [112] \\
"The design and \\
implementation of a \\
biodiversity offset should be \\
based on an adaptive \\
management approach, \\
incorporating monitoring and \\
evaluation, with the objective \\
of securing outcomes that last \\
at least tas long as the project's \\
impacts and preferably in \\
perpetuity." [112]
\end{tabular} & $\begin{array}{l}\text { Managed } \\
\text { through } \\
\text { conditions }\end{array}$ & [112] \\
\hline Colombia & $\begin{array}{l}\text { National } \\
\text { offsetting policy }\end{array}$ & $\begin{array}{l}\text { resolution } 1517 \text { of } 2012 \\
\text { and associated offsetting } \\
\text { manual }\end{array}$ & $\begin{array}{l}\text { "to ensure the effective } \\
\text { conservation of an } \\
\text { ecologically equivalent } \\
\text { area where a permanent } \\
\text { conservation strategyand/ } \\
\text { or ecological restoration } \\
\text { can be generated, so that } \\
\text { when comparing with the } \\
\text { baseline, the net loss of } \\
\text { biodiversity is guaranteed" } \\
{[113]^{5}}\end{array}$ & No & $\begin{array}{l}\text { Covers all } \\
\text { biodiversity but } \\
\text { marine application of } \\
\text { the policy is currently } \\
\text { not considered in the } \\
\text { manual for the } \\
\text { implementation of } \\
\text { offsets. }\end{array}$ & PRM & Yes & $\begin{array}{l}\text { "Ecologically equivalent area } \\
\text { selected for compensation } \\
\text { must meet } \\
\text { the following criteria: } \\
\text { a) be the same type of } \\
\text { affected natural ecosystem. } \\
\text { b) be equivalent to the size or } \\
\text { area to compensate the } \\
\text { fragment ecosystem } \\
\text { shocked. } \\
\text { c) Equal or greater and } \\
\text { landscape context fragment } \\
\text { ecosystem } \\
\text { shocked. } \\
\text { d) Equal to or greater species } \\
\text { richness fragment impacted } \\
\text { the ecosystem. } \\
\text { e) that is located in the area of } \\
\text { influence of the project." } 5 \\
\text { [114] }\end{array}$ & & $\begin{array}{l}\text { "They should be performed at } \\
\text { least equivalent to the lifetime } \\
\text { of the project period." [114] } \\
\text { "...operating and investment } \\
\text { plan to develop the process of } \\
\text { signing agreements } \\
\text { conservation opportunity costs } \\
\text { of land development for a } \\
\text { period } \\
\text { not less than the duration or life } \\
\text { of the project, work or activity." } \\
{[114]^{5}}\end{array}$ & $\begin{array}{l}\text { Managed } \\
\text { through } \\
\text { conditions }\end{array}$ & {$[113,114]$} \\
\hline Chile & $\begin{array}{l}\text { Biodiversity } \\
\text { markets }\end{array}$ & $\begin{array}{l}\text { Independent project } \\
\text { habitat bank }\end{array}$ & \begin{tabular}{|l|l} 
To provide innovative \\
financing for marine \\
protection using territorial \\
user rights for fisheries \\
(TURFs).
\end{tabular} & Yes & & & & & & \begin{tabular}{|l}
$\begin{array}{l}\text { creation } \\
\text { credits. }^{6}\end{array}$ of biodiversity \\
\end{tabular} & $\begin{array}{l}\text { Market } \\
\text { managed } \\
\text { through non- } \\
\text { profit } \\
\text { 'broker'.7 } \\
\end{array}$ & {$[115-117]$} \\
\hline $\begin{array}{l}\text { US } \\
\text { Islands }\end{array}$ & & $\begin{array}{l}\text { US Territory - subject to } \\
\text { US compensatory } \\
\text { mitigation requirements. }\end{array}$ & & & & & & & & & & \\
\hline Peru & \begin{tabular}{|l} 
Emergent \\
national \\
offsetting policy
\end{tabular} & & \begin{tabular}{|l} 
"to ensure NNL of \\
biodiversity resulting from \\
investment from large- \\
scale infrastructure \\
development projects in \\
the country" $[118]$
\end{tabular} & No & $\begin{array}{lr}\text { Guidelines } & \text { for } \\
\text { marine } & \text { habitats } \\
\text { expected } & \text { to be } \\
\text { developed } & \end{array}$ & & & & & & & [118] \\
\hline
\end{tabular}




\begin{tabular}{|c|c|c|c|c|c|c|c|c|c|c|c|c|}
\hline \multirow[b]{2}{*}{ Country } & \multicolumn{2}{|c|}{ Offset mechanism } & \multirow[b]{2}{*}{ Aim } & \multirow[b]{2}{*}{$\begin{array}{l}\text { Marine } \\
\text { specific }\end{array}$} & \multirow[b]{2}{*}{$\begin{array}{l}\text { Marine relevance if } \\
\text { not specific }\end{array}$} & \multirow[b]{2}{*}{$\begin{array}{l}\text { Instrument } \\
\text { used }\end{array}$} & \multirow[b]{2}{*}{\begin{tabular}{|l} 
Mitigation \\
hierarchy
\end{tabular}} & \multirow[b]{2}{*}{ Equivalence } & \multirow[b]{2}{*}{ Additionality } & \multirow[b]{2}{*}{ Continuity } & \multirow{2}{*}{$\begin{array}{l}\text { Compliance } \\
\text { success }\end{array}$} & \multirow[b]{2}{*}{ References } \\
\hline & Type & Detail & & & & & & & & & & \\
\hline Puerto Rico & & $\begin{array}{l}\text { US Territory - subject to } \\
\text { US compensatory } \\
\text { mitigation requirements. }\end{array}$ & & & & & & & & & & \\
\hline \multicolumn{13}{|l|}{ Oceania } \\
\hline $\begin{array}{l}\text { American } \\
\text { Samoa }\end{array}$ & & $\begin{array}{l}\text { US Territory - subject to } \\
\text { US compensatory } \\
\text { mitigation requirements. }\end{array}$ & & & & & & & & & & \\
\hline Guam & & $\begin{array}{l}\text { US Territory - subject to } \\
\text { US compensatory } \\
\text { mitigation requirements. }\end{array}$ & & & & & & & & & & \\
\hline New Zealand & National Policy & $\begin{array}{l}\text { Resource Management } \\
\text { Act } 1991 \text { (RMA) - not } \\
\text { applicable to offshore } \\
\text { marine areas unless } \\
\text { outlined within a regional } \\
\text { or district plan. [119] }\end{array}$ & & No & & & & & & & & [119] \\
\hline New Zealand & $\begin{array}{l}\text { Sub-national } \\
\text { policy }\end{array}$ & $\begin{array}{l}\text { Bay of Plenty Regional } \\
\text { Coastal Environment Plan }\end{array}$ & $\begin{array}{l}\text { "the sustainable } \\
\text { management of the natural } \\
\text { and physical resources of } \\
\text { the Bay of Plenty coastal } \\
\text { environment" }[120]\end{array}$ & No & $\begin{array}{l}\text { extends } 12 \text { nautical } \\
\text { miles offshore. [120] }\end{array}$ & PRM, ILF & \begin{tabular}{|l} 
Yes \\
(through \\
RMA 1991)
\end{tabular} & $\begin{array}{l}\text { "Significance residual adverse } \\
\text { effects...are offset to result in } \\
\text { no net loss and preferably a } \\
\text { net indigenous biological } \\
\text { diversity gain" [120] }\end{array}$ & $\begin{array}{l}\text { A biodiversity offset should } \\
\text { achieve conservation outcomes } \\
\text { above and beyond results that } \\
\text { would have occurred if the } \\
\text { offset had not taken place." } \\
{[120]}\end{array}$ & $\begin{array}{l}\text { "The design and } \\
\text { implementation of a } \\
\text { biodiversity offset should be } \\
\text { based on an adaptive } \\
\text { management approach, } \\
\text { incorporating } \\
\text { monitoring and } \\
\text { evaluation, with the objective } \\
\text { of securing outcomes that last } \\
\text { at least as long as the project's } \\
\text { impacts and preferably in } \\
\text { perpetuity" [120] }\end{array}$ & \begin{tabular}{|l} 
Managed \\
through \\
conditions
\end{tabular} & [120] \\
\hline New Zealand & $\begin{array}{l}\text { Sub-national } \\
\text { policy }\end{array}$ & $\begin{array}{l}\text { Proposed Marlborough } \\
\text { Environment Plan }\end{array}$ & 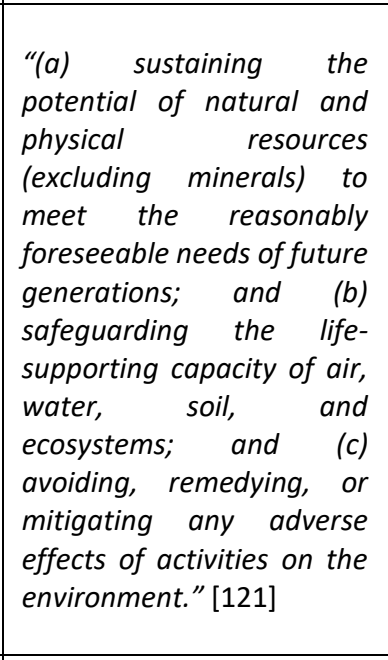 & No & $\begin{array}{l}\text { "The purpose of } \\
\text { regional and district } \\
\text { plans is to assist the } \\
\text { Council in carrying } \\
\text { out its functions in } \\
\text { order to achieve the } \\
\text { purpose of the RMA } \\
\text { and specifically for a } \\
\text { regional coastal plan, } \\
\text { to achieve the } \\
\text { purpose of the RMA } \\
\text { in relation to the } \\
\text { coastal marine } \\
\text { area." [121] }\end{array}$ & & Yes & $\begin{array}{l}\text { "The goal of a biodiversity } \\
\text { offset is to ochieve no net loss } \\
\text { and preferably a net gain of } \\
\text { biodiversity with respect to } \\
\text { species composition, habitat } \\
\text { structure and ecosystem } \\
\text { functions. It is therefore } \\
\text { important that offsets are } \\
\text { appropriate compensation. } \\
\text { There is a preference for the } \\
\text { reestablishment or protection } \\
\text { of the same type of ecosystem } \\
\text { or habitat to avoid the } \\
\text { difficulty of assessing relative } \\
\text { values of ilfferent ecosystems } \\
\text { or habitats of different } \\
\text { species" }[121] \\
\end{array}$ & & $\begin{array}{l}\text { "There also needs to be } \\
\text { certainty that the proposed } \\
\text { offsets will occur." [121] }\end{array}$ & \begin{tabular}{|l} 
Managed \\
through \\
conditions
\end{tabular} & [121] \\
\hline New Zealand & $\begin{array}{l}\text { Sub-national } \\
\text { policy }\end{array}$ & $\begin{array}{l}\text { Waikato Regional Policy } \\
\text { Statement }\end{array}$ & $\begin{array}{l}\text { "to maintain the full range } \\
\text { of ecosystem types and } \\
\text { maintain or enhance their } \\
\text { spatial extent as necessary } \\
\text { to achieve healthy } \\
\text { ecological functioning of } \\
\text { ecosystems" [122] }\end{array}$ & No & $\begin{array}{l}\text { "marine and } \\
\text { estuarine } \\
\text { ecosystems" [122] }\end{array}$ & & $\begin{array}{l}\text { Yes } \\
\text { (through } \\
\text { RMA 1991) }\end{array}$ & $\begin{array}{l}\text { "...proposals should } \\
\text { reasonably demonstrate that } \\
\text { no net loss has been achieved } \\
\text { using methodology that is } \\
\text { appropriate and } \\
\text { commensurate to the scale } \\
\text { and intensity of the adverse } \\
\text { effects." [122] }\end{array}$ & "“ & & \begin{tabular}{|l} 
Managed \\
through \\
conditions
\end{tabular} & {$[119,122]$} \\
\hline
\end{tabular}




\begin{tabular}{|c|c|c|c|c|c|c|c|c|c|c|c|c|}
\hline \multirow[b]{2}{*}{ country } & \multicolumn{2}{|c|}{ Offset mechanism } & \multirow[b]{2}{*}{ Aim } & \multirow{2}{*}{$\begin{array}{l}\text { Marine } \\
\text { specific }\end{array}$} & \multirow{2}{*}{$\begin{array}{l}\text { Marine relevance if } \\
\text { not specific }\end{array}$} & \multirow{2}{*}{$\begin{array}{l}\text { Instrument } \\
\text { used }\end{array}$} & \multirow{2}{*}{$\begin{array}{l}\text { Mitigation } \\
\text { hierarchy }\end{array}$} & \multirow[b]{2}{*}{ Equivalence } & \multirow[b]{2}{*}{ Additionality } & \multirow[b]{2}{*}{ Continuity } & \multirow{2}{*}{$\begin{array}{l}\text { Compliance } \\
\text { success }\end{array}$} & \multirow[b]{2}{*}{ References } \\
\hline & Type & Detail & & & & & & & & & & \\
\hline $\begin{array}{l}\text { Northern } \\
\text { Mariana Islands }\end{array}$ & & $\begin{array}{l}\text { US Territory - subject to } \\
\text { US compensatory } \\
\text { mitigation requirements. }\end{array}$ & & & & & & & & & & \\
\hline $\begin{array}{l}\begin{array}{l}\text { Papua } \\
\text { Guinea }\end{array} \\
\text { New }\end{array}$ & $\begin{array}{l}\text { Corporate } \\
\text { standards }\end{array}$ & 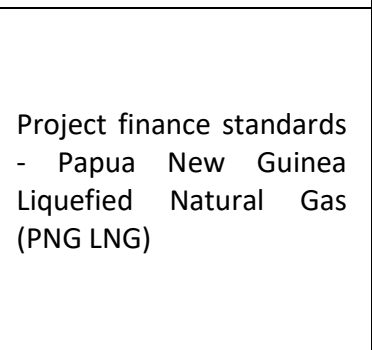 & $\begin{array}{l}\text { No net loss against IFC } \\
\text { Performance standard } 6 .\end{array}$ & No & $\begin{array}{l}\text { An element of the } \\
\text { biodiversity } \\
\text { offsetting proposal } \\
\text { included a kikori } \\
\text { dolphin project' to } \\
\text { improve } \\
\text { understanding and } \\
\text { protection of the } \\
\text { species. }\end{array}$ & & & 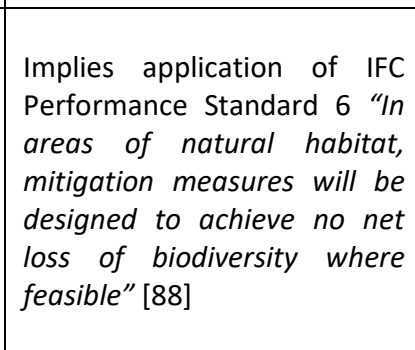 & & & & {$[88,123,124]$} \\
\hline
\end{tabular}


[1] DoD, EPA, Memorandum of Agreement Between the Environmental Protection Agency and the Department of the Army Concerning the Determination of Mitigation Under the Clean Water Act Section 404(b)(1) Guidelines, 1990.

[2] Environmental Protection Agency, Section 404(b)(1) Guidelines for Specification of Disposal Sites for Dredged or Fill Material, 2008. http://water.epa.gov/lawsregs/rulesregs/cwa/upload/CWA_Section404b1_Guidelines_40CFR230_July2010.pdf.

[3] US EPA, Summary of the Clean Water Act, (2015). http://www.epa.gov/laws-regulations/summary-clean-water-act (accessed December 15, 2015).

[4] S. Broad, Seagrass Mitigation Banks and the Governor's Veto, Stetson L. Rev. 19594 (2009) 66-67. http://heinonlinebackup.com/hol-cgi-bin/get_pdf.cgi?handle=hein.journals/stet39\&section=12 (accessed October 8, 2014).

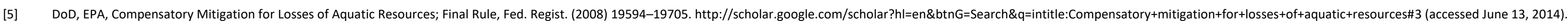

[6] J. Wilkinson, In-lieu fee mitigation: coming into compliance with the new Compensatory Mitigation Rule, Wetl. Ecol. Manag. 17 (2008) 53-70. doi:10.1007/s11273-008-9120-8.

[7] T. BenDor, J.A. Riggsbee, A survey of entrepreneurial risk in U.S. wetland and stream compensatory mitigation markets, Environ. Sci. Policy. 14 (2011) 301-314. doi:10.1016/j.envsci.2010.12.011.

[8] T. BenDor, J.A. Riggsbee, Regulatory and ecological risk under federal requirements for compensatory wetland and stream mitigation, Environ. Sci. Policy. 14 (2011) 639-649. doi:10.1016/j.envsci.2011.05.005.

[9] R. Kormos, D. Mead, B. Vinnedge, Biodiversity offsetting in the United States : Lesson learned on maximizing their ecological contribution, (2015).

[10] US EPA, Summary of the Endangered Species Act, (2015). http://www.epa.gov/laws-regulations/summary-endangered-species-act (accessed December 16, 2015).

[11] NOAA Fisheries, Endangered and Threatened Marine Species under NMFS' Jurisdiction, (2015). http://www.nmfs.noaa.gov/pr/species/esa/listed.htm (accessed August 19, 2015).

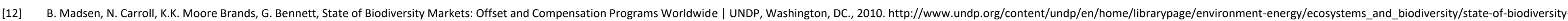
markets-offset-and-compensation-programs-worldwide/ (accessed April 17, 2014).

[13] M. Bauer, J. Fox, M.J. Bean, Landowners Bank on Conservation: The U.S. Fish and Wildlife Service's Guidance on Conservation Banking, Environ. Law Report. (2004) 10717-10722. http://www.forest-trends.org/documents/files/doc_603.pdf (accessed April 17, 2014).

[14] NOAA, Magnuson-Stevens Fishery Conservation and Management Act, U.S. Government, 2007. http://www.nmfs.noaa.gov/sfa/laws_policies/msa/ (accessed December 8, 2016).

[15] Office of Sustainable Fisheries, Magnuson-Stevens Fishery Conservation and Management Act :: Office of Sustainable Fisheries, (n.d.).

[16] NOAA Fisheries: West Coast Region, California Eelgrass Mitigation Policy and Implementing Guidelines, 2014

[17] DFO, Policy for the Management of Fish Habitat, 1986. http://www.gov.pe.ca/photos/original/elj_appendixd.pdf (accessed April 10, 2015).

[18] Fisheries and Oceans Canada, Policy for the Management of Fish Habitat, Ontario, 1986

[19] DFO, Practitioners Guide to Habitat Compensation, (2002). http://www.dfo-mpo.gc.ca/Library/270280.pdf (accessed April 10, 2015).

[20] Minister of Justice, Fisheries Act, Government of Canada, 1985. http://laws-lois.justice.gc.ca.

[21] J.T. Quigley, D.J. Harper, Effectiveness of fish habitat compensation in Canada in achieving no net loss., Environ. Manage. 37 (2006) 351-366. doi:10.1007/s00267-004-0263-y.

[22] D.J. Harper, J.T. Quigley, No net loss of fish habitat: a review and analysis of habitat compensation in Canada., Environ. Manage. 36 (2005) 343-355. doi:10.1007/s00267-004-0114-X.

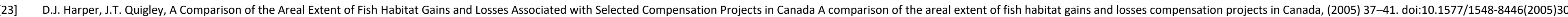

[24] D.J. Harper, J.T. Quigley, No net loss of fish habitat: An audit of forest road crossings of fish-bearing streams in British Columbia, 1996-1999, Can. Tech. Rep. Fish. Aquat. Sci. (2000) v-vi; 1-44.

[25] J.T. Quigley, D.J. Harper, Compliance with Canada's Fisheries Act: a field audit of habitat compensation projects., Environ. Manage. 37 (2006) 336-50. doi:10.1007/500267-004-0262-z.

[26] DFO, Fisheries Productivity Investment Policy: A Proponent's Guide to Offsetting, Ottowa, 2013. http://www.dfo-mpo.gc.ca/pnw-ppe/offsetting-guide-compensation/index-eng.html\#pt2_2

[27] Government of Canada, The federal policy on wetland conservation, Ontario, 1991.

[28] P. Lynch-Stewart, P. Neice, C. Rubec, I. Kessel-Taylor, The Federal Policy On Wetland Conservation, Ottawa, Ontario, 1996

[29] E. Austen, A. Hanson, An Analysis of Wetland Policy in Atlantic Canada, Can. Water Resour. J. 32 (2007) 163-178. doi:10.4296/cwrj3203163.

[30] C.D.A. Rubec, A.R. Hanson, Wetland mitigation and compensation: Canadian experience, Wetl. Ecol. Manag. 17 (2008) 3-14. doi:10.1007/s11273-008-9078-6.

[31] Australian Government, Environment Protection and Biodiversity Conservation Act 1999: Environmental Offsets Policy, Departement of Sustainability, Environment, Water, Population and Communities, Canberra, 2012.

[32] Department of the Environment and Energy, Environment Protection and Biodiversity Conservation Act 1999 (EPBC Act), Australian Government, Canberra, 1999. https://www.legislation.gov.au/Details/C2016C00777 (accessed December 16, 2015).

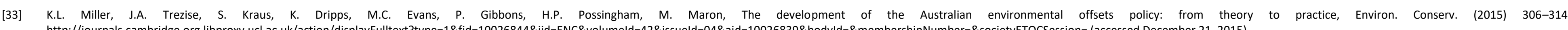
http://journals.cambridge.org.libproxy.ucl.ac.uk/action/displayFulltext?type=1\&fid=10026844\&.jid=ENC\&volumeld=42\&issueld=04\&aid=10026839\&bodyld=\&membershipNumber=\&societyETOCSession= (accessed December 21, 2015)

[34] Business and Biodiversity Offsets Programme (BBOP), Standard on Biodiversity Offsets, Washington, D.C., 2012. http://bbop.forest-trends.org/guidelines/Standard.pdf. 
W. Bull, K.B. Suttle, A. Gordon, N.J. Singh, E.J. Milner-Gulland, Biodiversity offsets in theory and practice, Oryx. 47 (2013) 369-380.

Queensland Government, Queensland Environmental Offsets Policy (version 1.2), Biodiversity Integration and Offsets, Department of Environment and Heritage Protection, Australia, 2016.

[38] Queensland Government, Environmental Offsets Regulation 2014, 2014

[39] G. Dutson, L. Bennun, M. Maron, J. Brodie, M. Bos, J. Waterhouse, Determination of suitable financial contributions as offsets within the Reef Trust, Cambridge, 2015.

[40] M. Maron, M. Walsh, N. Shumway, J. Brodie, Reef Trust Offsets Calculator, Brisbane, Queensland, Australia, 2016.

[41] S. Fairfull, Fisheries NSW Policy and guidelines for fish habitat conservation and management, Wollongbar, 2013. doi:ISBN 9781742562834.

[42] NSW Government, Fisheries Management Act 1994 № 38, 1994.

[43] Victoria State Government, Victoria Planning Provisions, Minister for Planning, Melbourne, Victoria, Australia, 2016.

[44] Department of Environment and Primary Industries, State Government Victoria, Permitted clearing of native vegetation: Biodiversity assessment guidelines, 2013.

[45] Victoria State Governement, Alternative specific offset arrangements What must be included, 2015.

[46] Government of Western Australia, WA Environmental Offsets Guidelines, Perth, WA, 2014.

[47] Government of Western Australia, Environmental Protection Act 1986, Perth, WA, 1986

[48] Government of Western Australia, WA Environmental Offsets Policy, Perth, WA, 2011.

[49] Environmental Protection Authority, Environmental Assessment Guideline for Protecting Marine Turtles from Light Impacts, 2010.

[50] Environmental Protection Authority, Environmental assessment guidelines No.3: Protection of benthic primary producer habitats in Western Australia's marine environment, 2009.

[51] Environmental Protection Authority, Environmental Assessment Guidelines Environmental Assessment Guideline for Marine Dredging Proposals, 2011.

[52] Environmental Protection Authority, Environmental Assessment Guidelines Environmental Assessment Guideline for Protecting the Quality of Western Australia's Marine Environment, 2015.

[53] Department of Environment Water and Natural Resources, Policy for Significant Environmental Benefit, Adelaide, South Australia, 2015. doi:10.1002/ejoc.201200111.

[54] Government of South Australia, Native Vegetation Act 1991, Adelaide, South Australia, 1991.

[55] Government of South Australia, Native Vegetation Regulations 2003, 2003.

[56] M. Conway, M. Rayment, A. White, S. Berman, Exploring potential demand for and supply of habitat banking in the EU and appropriate design elements for a habitat banking scheme, London, 2013.

[57] G. Tucker, B. Allen, M. Conway, I. Dickie, K. Hart, M. Rayment, C. Schulp, A. van Teeffelen, Policy options for an EU no net loss initiative. Report to the European Commission, London, 2014.

[58] European Commission, Our Life Insurance, Our Natural Capital: An EU Biodiversity Strategy to 2020, Brussels, Belgium, 2011.

[59] European Commission, Guidance document on Article 6 (4) of the "Habitats Directive" 92/43/EEC, 2012.

[60] European Commission, MANAGING NATURA 2000 SITES The provisions of Article 6 of the "Habitats" Directive 92/43/CEE, Luxembourg, 2000.

[61] Natural England, Natural England Guidance Note: European Protected Species and the Planning Process, 2010

[62] European Commission, Council Directive 92/43/EEC of 21 May 1992 on the conservation of natural habitats and of wild fauna and flora, European Commission, 1992.

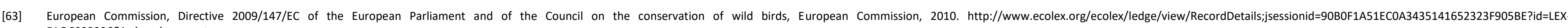
FAOC092236\&index=documents.

[64] F. Quétier, B. Regnery, H. Levrel, No net loss of biodiversity or paper offsets? A critical review of the French no net loss policy, Environ. Sci. Policy. 38 (2014) 120-131. doi:10.1016/j.envsci.2013.11.009.

[65] MEDDE, Lignes directrices nationales sur la sequence eviter, reduire et compenser les impacts sur les milieux naturels., Ministere de l'Ecologie, du Developpement Durable et de l'Energie, Paris, France, 2013.

[66] B. Regnery, C. Kerbiriou, R. Julliard, J.-C. Vandevelde, I. Le Viol, M. Burylo, D. Couvet, Sustain common species and ecosystem functions through biodiversity offsets: response to Pilgrim et al ., Conserv. Lett. (2013) n/a-n/a. doi:10.1111/conl.12027.

[67] MEDDE, Doctrine relative a la sequence eviter, reduire et compenser les impacts sur le milieu naturel, Ministere de l'Ecologie, du Developpement Durable et de l'Energie, Paris, France, 2012.

[68] MEDDE, Guide Especes protegees, amegenagements et infrastructures, Ministere de l'Ecologie, du Developpement Durable et de l'Energie, Paris, France, 2012.

[69] Federal Ministry for the Environment Nature Conservation and Nuclear Safety, Act on Nature Conservation and Landscape Management (Federal Nature Conservation Act - BNatSchG) of 29 July 2009, 2010. www.bmub.bund.de/N46170-1/. 
S. de Bie, B. van Dessel, Compensation For Biodiversity Loss - Advice to the Netherlands' Taskforce on Biodiversity and Natural Resource, Klarenbeek, 2011

. Dickie, L. McAleese, B. Pearce, J. Treweek, Marine Biodiversity Offsetting - UK Scoping Study, London, 2013.

[72] DEFRA, Biodiversity Offsetting in England: Green paper, DEFRA, 2013.

[73] D. Cook, N. Clay, Marine Biodiversity Offsetting and Habitat Banking Feasibility Study, London, 2013.

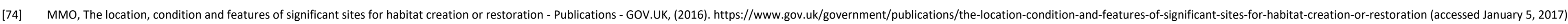

[75] P. Chadwick, J. Duncan, K. Tunley, State of Management of South Africa's Marine Protected Areas, 2014

[76] N. Jenner, Z. Balmforth, Biodiversity offsets: Lessons learnt from policy and practice. Country summary report: South Africa, Cambridge, 2015. doi:www.fauna-flora.org.

[77] Ezemvelo KZN Wildlife, Concise Guideline: Biodiversity Offsets in KwaZulu Natal, 2013. doi:10.1002/ejoc.201200111.

[78] Department of Environmental Affairs and Development Planning, Provincial guideline on biodiversity offsets, Cape Town, 2007.

[79] D. Macfarlane, S.D. Holness, A. von Hase, S. Brownlie, J. Dini, Wetlands offsets: a best-practice guideline for South Africa., Pretoria, 2014. doi:10.1017/CBO9781107415324.004.

[80] Republic of South Africa, National Environment Management Act (NEMA) (Act 107, 1998), n.d.

[81] Republic of South Africa, No. 107 of 1998: National Environmental Management Act, 1998, 1998.

[82] Republic of South Africa, Act No. 36 of 2014. National Environmental Management: Integrated Coastal Management Amendment Act, 2014, 2014. doi:102GOU/B.

[83] Republic of South Africa, Marine Living Resources Act (Act No. 18 of 1998), 1998.

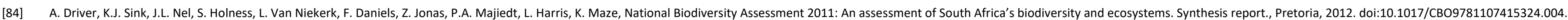

[85] J.M. Harris, T. Livingstone, A.. Lombard, E. Lagabrielle, P. Haupt, K.J. Sink, M.J. Schleyer, B.Q. Mann, Coastal and Marine Biodiversity Plan for KwaZulu-Natal. Spatial priorities for the conservation of coastal and marine biodiversity in KwaZulu-Natal., (2012).

[86] S. Brownlie, M. Botha, Biodiversity offsets: adding to the conservation estate, or "no net loss"?, Impact Assess. Proj. Apprais. 27 (2009) 227-231. doi:10.3152/146155109X465968.

[87] S. Johnson, A national biodiversity offset scheme : a road map for Liberia's mining sector, 2015. http://documents.worldbank.org/curated/en/2015/04/24418254/national-biodiversity-offset-scheme-road-map-liberia's-mining-sector.

[88] IFC, Performance Standard 6: Biodiversity Conservation and Sustainable Management of Living Natural Resources, 2012. www.ifc.org.

[89] Ministry of Foreign Affairs, An Act Adopting the Environment Protection and Management Law of the Republic of Liberia, Environmental Protection Agency, Monrovia, Liberia, 2002.

[90] Republic of Mozambique, Petroleum law no. 21/2014, dated 18th August, 2014.

[91] Republic of Mozambique, Mozambique National Reporting to Commission on Sustainable Development 18-19, section on Mining., 2010. http://www.un.org/esa/dsd/dsd_aofw_ni//ni_pdfs/NationalReports/mozambique/Mining.pdf.

[92] M. Moye, S. Nazerali, Feasibility Study : Sustainable Financing of Protected Areas in Mozambique. Prepared with support from UNDP-GEF., Maputo, Mozambique, 2010.

[93] Peace Parks Foundation, Building the future of biodiversity conservation in Mozambique, (2015). http://www.peaceparks.org/news.php?pid=1481\&mid=1528\&o=0\&q=biofund (accessed May 11, 2016).

[94] WWF, Building the Future of Biodiversity Conservation in Mozambique, (2015). http://www.worldwildlife.org/projects/building-the-future-of-biodiversity-conservation-in-mozambique (accessed May 11, 2016).

[95] BIOFUND, Biofund, (2016). http://www.biofund.org.mz/en/ (accessed May 11, 2016).

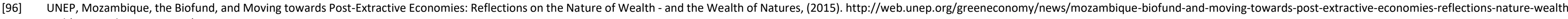
and (accessed May 11, 2016).

[97] Tullow Oil, 2009 Corporate Responsibility Report, (2009). http://www.tullowoil.com/Media/docs/default-source/3_investors/2009-tullow-cr-report.pdf?sfursn=2 (accessed December 18, 2015).

[98] Tullow Oil and WCS initiate a vast research project on the marine environment, Le Gabon.org. (2012). http://www.en.legabon.org/news/1241/tullow-oil-and-wcs-initiate-vast-research-project-marine-environment (accessed August 20, 2015).

[99] Tullow Oil, Biodiversity Research with the Wildlife Conservation Society, 2013. (n.d.). http://www.tullowoil.com/media/case-studies/biodiversity-research-with-the-wildlife-conservation-society (accessed August 20, 2015).

[100] H. Rao, C. Lin, H. Kong, D. Jin, B. Peng, Ecological damage compensation for coastal sea area uses, Ecol. Indic. 38 (2014) 149-158. doi:10.1016/j.ecolind.2013.11.001.

[101] SOA, Several Opinions on Better Protection and Construction of Marine Ecosystem, Beijing, 2009.

[102] B. Peng, W. Chen, H. Hong, Integrating ecological damages into the user charge for land reclamation: a case study of Xiamen, China, Stoch. Environ. Res. Risk Assess. 25 (2010) 341-351. doi:10.1007/s00477-010-0372-5

[103] Ministry of Land Transport and Maritime Affairs - Marine Environmental Policy Division, Marine Environment Management Act (English translation), Government of South Korea, 2009.

[104] Ministry of Environment of the Republic of Korea, The Fifth National Report ot the Convention on Biological Diversity, Sejong Special Self-Governing City, Korea, 2014. 
[105] OECD, OECD environmental performance reviews: Korea, Paris, France, 2006.

[106] S.G. Kim, The evolution of coastal wetland policy in developed countries and Korea, Ocean Coast. Manag. 53 (2010) 562-569. doi:10.1016/j.ocecoaman.2010.06.017.

[107] J.-Y. Lee, Current status, policies and challenges for Marine Protected Areas in Korea, (2013). http://www.neaspec.org/sites/default/files/3-3_Republic_of_Korea.pdf (accessed December 18, 2015).

[108] Ministry of Environment of the Republic of Korea, Korea's National Biodiversity Strategy 2014-2018, Sejong Special Self-Governing City, Korea, 2014.

[109] Ministry of Economic Affairs, Convention on Biological Diversity - Fifth National Report of the Kingdom of the Netherlands, The Hague, 2014. http://www.cbd.int/default.shtml.

[110] Yemen LNG, Yemen LNG Company Biodiversity Action Plan, 2008. http://www.yemenlng.com/ws/uploads/bap-31-10-08.pdf (accessed January 20, 2017).

[111] Republic of Argentina, Ley General del Ambiente, Buenos Aires, 2002.

[112] Belize Coastal Zone Management Authority \& Institute and Australia-Caribbean Coral Reef Collaboration, Marine and coastal biodiversity offsets framework for Belize, Townsville, 2014. http://climateandreefs.org/biodiversity-offsets/.

[113] Ministerio de Ambiente y Desarrollo Sostenible (MADS), Manual Para La Asignacion de Compensaciones por Perdida de Biodiversidad, ANLA, 2012. [114] Ministerio de Ambiente y $\underset{\text { D }}{\text { Desarrollo }}$ Sostenible (MADS), Resolution $1517, \quad 31 \quad$ Aug 2012 “Por la
http://www.anla.gov.co/documentos/normativa/13992_Resolucion_1517_2012_Adopta_manual_compensac_perdida_biodiversidad.pdf.

[115] S. Gelcich, C.J. Donlan, Incentivizing biodiversity conservation in artisanal fishing communities through territorial user rights and business model innovation, Conserv. Biol. 29 (2015) 1076-1085. doi:10.1111/cobi.12477.

[116] J.C. Castilla, P. Manriquez, J. Alvarado, A. Rosson, C. Pino, C. Espoz, R. Soto, D. Oliva, O. Defeo, Artisanal “caletas” as units of production and co-managers of benthic invertebrates in Chile, Can. Spec. Publ. Fish. Aquat. Sci. 125 (1998) 407-413.

[117] S. Gelcich, M. Fernández, N. Godoy, A. Canepa, L. Prado, J.C. Castilla, Territorial user rights for fisheries as ancillary instruments for marine coastal conservation in Chile., Conserv. Biol. 26 (2012) 1005-15. doi:10.1111/j.1523-1739.2012.01928.x.

[118] E. Pilla, Towards the Development of Metrics for No Net Loss of Biodiversity in Peru, Washington, D.C., 2014.

[119] New Zealand Government, Guidance on Good Practice Biodiversity Offsetting in New Zealand, 2014.

[120] Bay of Plenty Regional Council, Proposed Bay of Plenty Regional Coastal Environment Plan, Whakatane, 2015.

[121] Marlborough District Council, Proposed Marlborough Environment Plan, Marlborough District Council, Blenheim, New Zealand, 2016. http://www.marlborough.govt.nz/Your-Council/RMA/The-Proposed-MEP.aspx.

[122] Waikato Regional Council, Waikato Regional Policy Statement, Hamilton, 2016.

[123] S. p. . D’Appolonia, Environmental \& social compliance monitoring: Papua New Guinea LNG Project. Site Visit: October 2015, 2015. http://www.pnglng.com/images/iese_pdfs/10-874-H15-IESC-Report-III-draft-final.pdf (accessed May 13, 2016).

[124] James Cook University, Rare Australian dolphin found in PNG waters, (2015). https://www.jcu.edu.au/news/releases/2015/september/rare-australian-dolphin-found-in-png-waters. 